\title{
PRC1 Prevents Replication Stress during Chondrogenic Transit Amplification
}

\author{
Frank Spaapen ${ }^{1}$, Lars M. T. Eijssen ${ }^{2,+}$, Michiel E. Adriaens ${ }^{3,+}$, Tim J. Welting ${ }^{4}$, \\ Peggy Prickaerts ${ }^{1}$, Juliette Salvaing ${ }^{1,5}$, Vivian E. H. Dahlmans ${ }^{1}$, Donald A. M. Surtel ${ }^{4}$,
} Frans Kruitz ${ }^{1}$, Roel Kuijer ${ }^{6}$ (D), Yoshihiro Takihara ${ }^{7}$, Hendrik Marks ${ }^{8}$ (D), Hendrik G. Stunnenberg ${ }^{8}$, Bradly G. Wouters ${ }^{9,10} \mathbb{C D}^{\circ}$, Miguel Vidal ${ }^{11}$ and Jan Willem Voncken ${ }^{1, *}$

1 Department of Molecular Genetics , Maastricht University Medical Center, Universiteitssingel 50-60, 6229ER Maastricht, The Netherlands; fa.spaapen@alumni.maastrichtuniversity.nl (F.S.); p.prickaerts@alumni.maastrichtuniversity.nl (P.P.); juliette.salvaing@cea.fr (J.S.); v.vanleeuwen@maastrichtuniversity.nl (V.E.H.D.); f.kruitz@alumni.maastrichtuniversity.nl (F.K.)

2 Department of Bioinformatics (BiGCaT), Maastricht University Medical Center, Universiteitssingel 50-60, 6229ER Maastricht, The Netherlands; 1.eijssen@maastrichtuniversity.nl

3 Maastricht Centre for Systems Biology-MaCSBio, Maastricht University Medical Center, Universiteitssingel 50-60, 6229ER Maastricht, The Netherlands; m.e.adriaens@maastrichtuniversity.nl

4 Department of Orthopedic Research, Maastricht University Medical Center, Universiteitssingel 50-60, 6229ER Maastricht, The Netherlands; t.welting@maastrichtuniversity.nl (T.J.W.);

dam.surtel@maastrichtuniversity.nl (D.A.M.S.)

5 Laboratoire de Physiologie Cellulaire et Végétale (LPCV), UMR 1417 INRA/UMR 5168 CNRS-CEA-UGA, Bioscience and Biotechnology Institute of Grenoble (BIG), Commissariat à l'Energie Atomique et aux Energies Renouvelables (CEA); 38054 Grenoble CEDEX 9, France

6 Department of Biomedical Engineering, University of Groningen, University Medical Center Groningen, Deusinglaan 1,9713AV Groningen, The Netherlands; r.kuijer@umcg.nl

7 Stem Cell Biology, Research Institute for Radiation Biology and Medicine, Hiroshima University, 1-2-3, Kasumi, Minami-ku, Hiroshima 734-8553, Japan; takihara@hiroshima-u.ac.jp

8 Department of Molecular Biology, Radboud Institute for Molecular Life Sciences (RIMLS), Radboud University, Geert Grooteplein 28, 6525GA Nijmegen, The Netherlands; h.marks@ncmls.ru.nl (H.M.); h.stunnenberg@ncmls.ru.nl (H.G.S.)

9 Maastricht Radiation Oncology (MaastRO) Laboratory, Maastricht University Medical Center, Universiteitssingel 50-60, 6229ER Maastricht, The Netherlands; bwouters@uhnresearch.ca

10 Medical Biophysics and Radiation Oncology, Princess Margaret Cancer Centre and Campbell Family Institute for Cancer Research, University Health Network, 610 University Avenue, Toronto, ON M5G 2M9, Canada

11 Department of Cell and Molecular Biology, Centro de Investigaciones Biológicas, Consejo Superior de Investigaciones Científicas, Velázquez 144, 28006 Madrid, Spain; mvidal@cib.csic.es

* Correspondence: w.voncken@maastrichtuniversity.nl; Tel.: +31-43-3882919

+ These authors contributed equally to this work.

Academic Editor: Luciano Di Croce

Received: 3 October 2017; Accepted: 24 November 2017; Published: 11 December 2017

\begin{abstract}
Transit amplification (TA), a state of combined, rapid proliferative expansion and differentiation of stem cell-descendants, remains poorly defined at the molecular level. The Polycomb Repressive Complex 1 (PRC1) protein BMI1 has been localized to TA compartments, yet its exact role in TA is unclear. PRC1 proteins control gene expression, cell proliferation and DNA-damage repair. Coordination of such DNA-templated activities during TA is predicted to be crucial to support DNA replication and differentiation-associated transcriptional programming. We here examined whether chondrogenesis provides a relevant biological context for synchronized coordination of these chromatin-based tasks by BMI1. Taking advantage of a prominently featuring TA-phase during chondrogenesis in vitro and in vivo, we here report that TA is completely dependent on intact PRC1 function. BMI1-depleted chondrogenic progenitors rapidly accumulate double strand
\end{abstract}


DNA breaks during DNA replication, present massive non-H3K27me3-directed transcriptional deregulation and fail to undergo chondrogenic TA. Genome-wide accumulation of Topoisomerase $2 \alpha$ and Geminin suggests a model in which PRC1 synchronizes replication and transcription during rapid chondrogenic progenitor expansion. Our combined data reveals for the first time a vital cell-autonomous role for PRC1 during chondrogenesis. We provide evidence that chondrocyte hyper-replication and hypertrophy represent a unique example of programmed senescence in vivo. These findings provide new perspectives on PRC1 function in development and disease.

Keywords: polycomb; topoisomerase; transit amplification; chromatin; DNA replication; transcription; chondrogenesis; differentiation; DNA damage; hypertrophy; senescence

\section{Introduction}

Throughout development, the cooperative action of Polycomb Repressive Complexes (PRCs) and their counterparts the Trithorax group proteins (TrxG) is thought to constitute part of an epigenetic transcriptional memory, vital for maintenance of cell identity [1-5]. Many PRC1-mutants display antero-posterior (A-P) patterning defects in insect and rodent models as a result of failing Hox gene expression-boundary maintenance. In mice, such defects are manifested as skeletal deformations, which are exacerbated by compound mutation [6]. In addition, PRC1-mutations are known to cause defects in DNA replication in Drosophila melanogaster syncytial larvae through as yet unknown mechanisms [7,8]. PRC1 proteins, among which BMI1 (B lymphoma Mo-MLV insertion region 1 homolog; PCGF4), control cell proliferation in normal and oncogenic contexts $[5,9,10]$. Besides its role in transcription and replication regulation, BMI1 is centrally positioned in DNA repair and its overexpression has been correlated to resistance to tumor therapy [11,12]. Thus, PRCs function in numerous DNA-templated processes, each with obvious importance for development, differentiation and tissue homeostasis.

We previously showed that the PRC1 protein RNF2 (Ring Finger protein 2; RING1B; RING2) controls cell proliferation during pre-HOX (E6-9) development via CDKN2A/P16 ${ }^{\mathrm{INK} 4 a}$ [13], in support of a cell-autonomous regulatory function of PRC1 in cell proliferation in post-implantation development. In addition, BMI1-depletion has been correlated to stem cell maintenance defects, among which in adult hematopoietic and adult peripheral and central nervous system (CNS) neural stem cells [14-16]. The underlying cell biological aspects thereof are, however, currently not entirely understood. Recent reports have also localized BMI1 to transit amplifying cell populations in developing tissues $[17,18]$. During transit amplification (TA), lineage-committed descendants of stem cells (progenitors) rapidly expand in numbers and simultaneously differentiate giving rise to differentiated cell lineages. By inference, DNA transcription, replication and repair require tight coordination during TA. Although recognized as an important transitional stage during which multiple chromatin-based activities, virtually nothing is known about how TA is controlled at the molecular level. Moreover, the biological relevance of BMI1 expression in the TA cell compartment is unknown.

Because of their functional versatility in regard to multiple chromatin-based processes, we hypothesized that PRC1 proteins represent candidate regulators of TA. We recently established that in the absence of the immediate early response gene EGR1, TA fails in a cell model for chondrogenesis [19]. Relevantly, EGR1 displays regulatory interaction with PRC proteins at multiple levels and EGR1-deficient cells show substantial reduction of BMI1 levels during the phase corresponding to the early differentiation-associated proliferative burst [19]. Although presumed to be involved in endochondral bone formation, a role for PRC1 proteins in chondrogenesis has not been studied before. In the current study, we probed a potential regulatory involvement of PRC1, in particular BMI1, during TA. To this end we focused on combining biologically relevant in vitro and in vivo chondrogenic models for chondrogenesis. Our results show for the first time that TA is 
completely dependent on PRC1: using dynamic in-depth transcriptomic and epigenomic analyses we prove that in the absence of functional PRC1, coordination of DNA-templated activities during TA fails and results in massive DNA damage. Defective proliferation and differentiation early in TA occur in the absence of major changes in global H3K27me3 marking. Instead, the inability to remove Topoisomerase $2 \alpha$ cleavable-complexes in the absence of BMI1 provides a thus far unknown molecular basis explaining for stalled replication and defective transcriptional control in PRC1-deficient cells.

\section{Results}

\subsection{Loss of PRC1 Prevents Transit Amplification and Reduces Chondrogenic Capacity}

The long bones of the mature ossified mammalian skeleton develop from a cartilaginous scaffold via a process called endochondral ossification [20]. One of the most iconic examples of a differentiation-associated amplifying (TA) cell population is the rapid expansion of chondrogenic progenitors in the proliferative zone (PZ) of growing long bones (Figure 1A). Relevantly, numerous PRC1-mutations have been linked to abnormal skeletogenesis in mice [6]. To probe for a cell-autonomous role for PRC1 in TA, i.e., independent of Hox-associated A-P positioning, we used murine ATDC5 cells, a well-defined in vitro model for chondrogenesis [21]. ATDC5 represent an early mesenchymal progenitor cell type, which can be induced to undergo adipogenesis, osteogenesis or chondrogenesis. Of note, ATDC 5 differentiation encompasses both a transit amplification of progenitor proliferation and chondrogenic transcriptional programming [21]. To assess their role in TA, we first verified murine growth plates for the presence of PRC1 proteins with reported single or compound mutant skeletal phenotypes [13,22-26]. PRC1 proteins BMI1, RNF2 and RING1 (RING1A) were clearly expressed in the PZ/pre-HZ (pre-hypertrophic zone) of active growth plates in the murine femur (Figure 1A). ATDC5 cells expressed and/or induced genes encoding PRC1 core-complex members during chondrogenesis, among which pcgf genes (4/Bmi1, 2/Mel18) ring1 genes (i.a. Ring1A, 1B/Rnf2), polyhomeotic-like (i.a. Phc1, 2), chromobox (i.a. Cbx2/M33, 4/Mpc2) and Rybp (Figure S1A). In line with its prominent localization to the $\mathrm{PZ} /$ pre-HZ, BMI1 protein expression was markedly induced in vitro at 6 days post-induction of differentiation (pid), suggesting an increased reliance of early chondrogenic ATDC5 differentiation on PRC1 function (Figure 1B). We used a short hairpin (sh) vector to reduce cellular BMI1; the shBmi1 vector efficiently reduced murine BMI1 levels at 6 days pid to less than $50 \%$ of a control sh vector (shcon) levels (Figure 1B). BMI1-depletion impeded differentiation as evidenced by altered Sox9 (biphasic chondrogenic marker) and Runx2 (late marker), collagen type II, $\alpha 1$ (Col2A1) and aggrecan (Acan); Figure 1C and Figure S1B) and reduced chondrogenic nodule formation in culture (data not shown; [21]). Conversely, over-expression of a murine Bmi1 (mBmi1) cDNA enhanced expression of chondrogenic makers during differentiation (Figure S1C-E). The above data is consistent with a role for BMI1 in chondrogenesis and validates the significance of the ATDC5 model to probe PRC1 function during TA. 
A

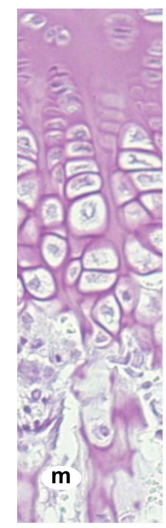

$\mathrm{hmtx}$
RZ

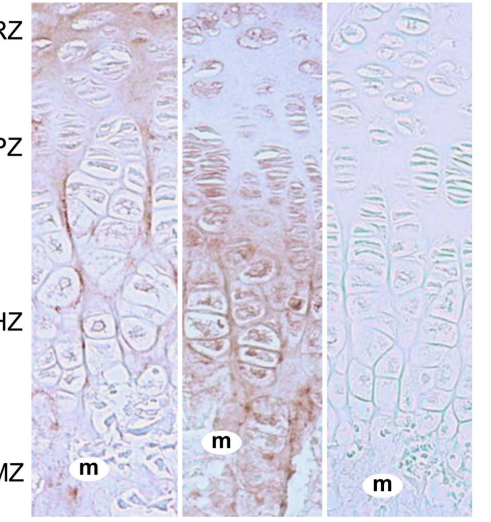

COL2A1 COL10A1 IgG

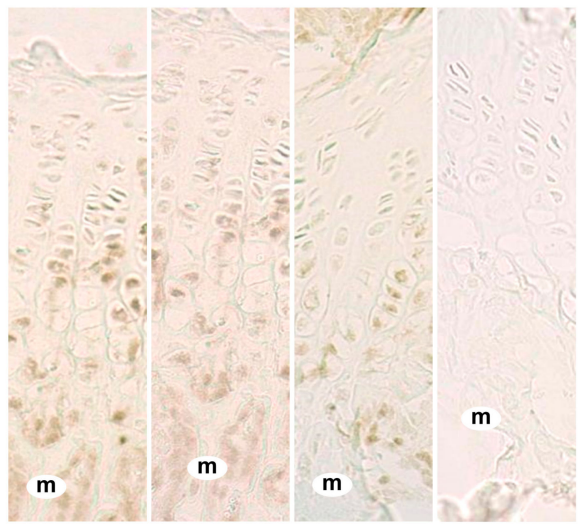

BMI1 RING1 RNF2 IgG

B

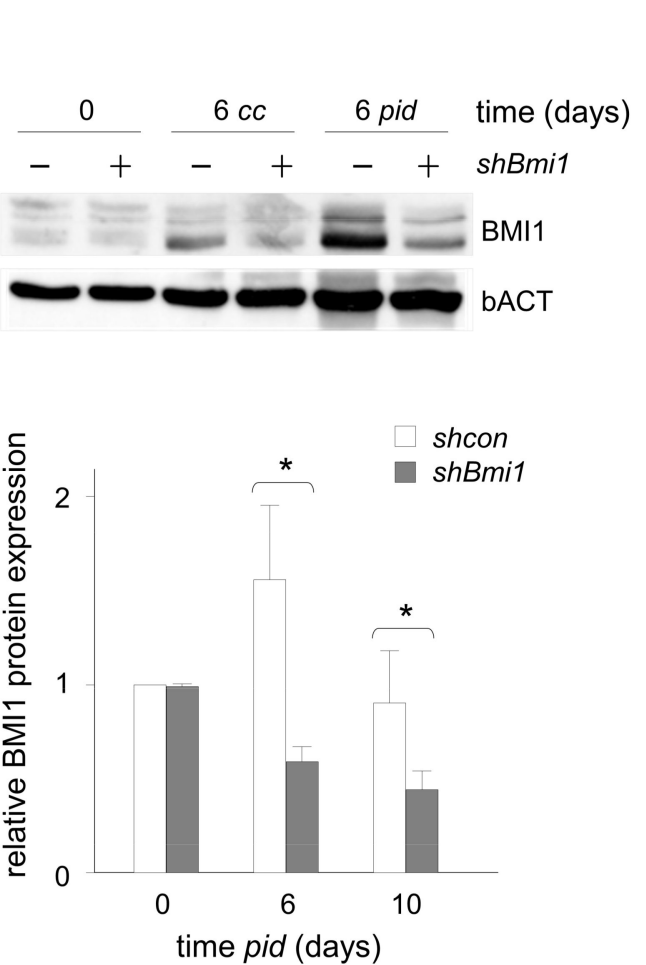

C

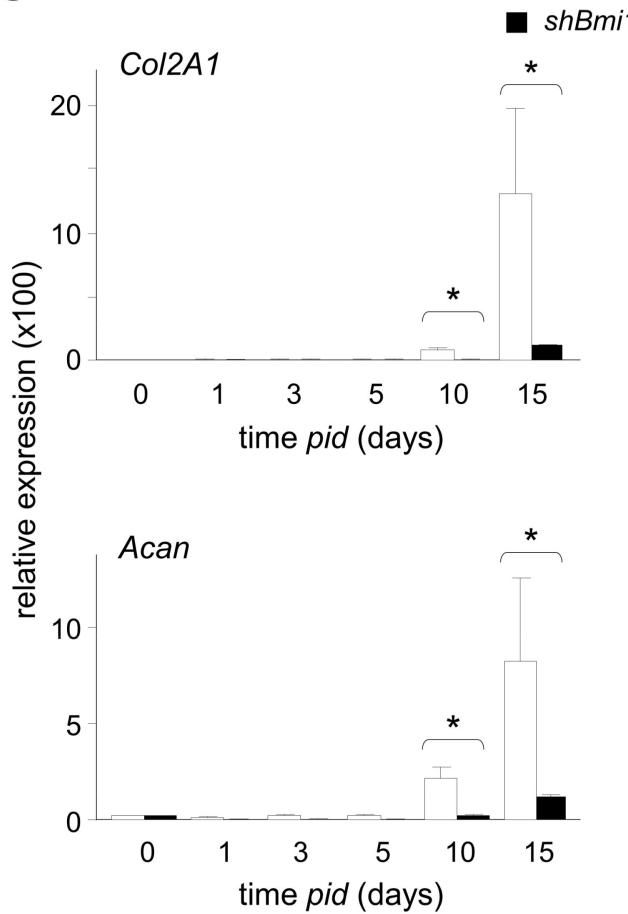

Figure 1. BMI1 is required for chondrogenic differentiation. (A) Histological sections of an active murine femoral growth plate: (left panel) hematoxylin (hmtx) stained section (RZ: resting zone, PZ: proliferation zone, $H Z$ : hypertrophic zone, $M Z$ : mineralization zone; $m$ : marrow spaces); immunohistochemical $(\mathrm{IH})$ staining on growth plate sections (middle panels) for COL2A1 (collagen type II; PZ marker), COL10A1 (collagen type X; HZ marker) and (right panels) for BMI1, RING1, RNF2; IgG was used as negative control in IH; (B) Representative comparative immunoblot (IB) analysis of BMI1 protein expression in ATDC5 cells stably expressing control (- shBmi1) or Bmi1 (+ shBmi1) shRNAs at $\mathrm{t}=6$ days post induction of differentiation (pid; $c c$ : non-differentiating conditions); bACT loading control. Lower panel: quantification of BMI1 protein knock-down at $\mathrm{t}=0,6$ and 10 days pid. BMI1 proteins levels were normalized to beta-Actin (bACT) levels; asterisks ${ }^{*}$ ): $p<0.05$; (C) Expression of chondrogenic markers Col2A1 and Acan mRNA in shcon vs. shBmi1 ATDC5 at indicted time-points pid (RT-qPCR analysis); asterisks ${ }^{*}$ ): $p<0.05$. pid (post-induction of differentiation), cc (non-differentiating, maintenance culturing conditions) 
We next examined the effect of BMI1-depletion on differentiation-associated TA using RNAi-mediated knock-down. Under maintenance (i.e., non-differentiating) culturing conditions, BMI1-depletion marginally affected cell proliferation rate (Figure 2A,B). Under chondrogenic differentiation conditions BMI1-proficient control (shcon) ATDC5 cells underwent a phase of rapid proliferative expansion (i.e., TA) between $t=1$ to 6 days pid (Figure 2A) which coincided with the observed BMI1 induction (cf. Figure 1B). In sharp contrast, BMI1-KD cells failed to undergo TA under differentiation conditions: their proliferation rate did not exceed that of non-differentiating (shcon or shBmi1) cells (Figure 2B). Reduced cell division in ATDC5 BMI1-KD cultures was confirmed by near complete absence of cells positive for late-S and G2/M-associated H3S10-phosphorylation (H3S10ph; Figure S2A). To obtain an objective, quantitative measurement for cell cycle progression, BrdU-incorporation and DNA profiles were compared under maintenance (i.e., non-differentiation; $\mathrm{t}=0$ ) and chondrogenic (i.e., differentiation; $\mathrm{t}=6$ days pid) conditions. At $\mathrm{t}=0$, no significant differences in cell cycle phase-distribution or de novo DNA synthesis between control and BMI1-KD cells were observed (Figure 2C and Figure S2B). In contrast, under differentiation conditions $(\mathrm{t}=6$ days pid), BMI1-KD cultures, showed a more than two-fold higher percentage of cells in S-phase (vs. shcon cells; Figure S2B); comparably low subG1 fractions under both conditions suggested apoptosis did not contribute significantly to the observed differences (Figure S2B). S-phase accumulation in shBmi1 cultures coincided with a dramatic reduction of BrdU-incorporation (i.e., de novo DNA synthesis; Figure 2C). In methanol-fixed cells, brightness and subnuclear distribution of the proliferating cell nuclear antigen (PCNA), a DNA clamp protein that acts as a DNA polymerase (DPOL)-associated processivity factor, reflect commitment to DNA-synthesis (i.e., S-phase) and S-phase progression, respectively [27]. As expected, most PCNA-bright shcon cells co-stained for BrdU at $\mathrm{t}=3$ days pid and had thus committed to DNA replication (Figure S2C). In clear contrast, numerous BMI1-deficient cells, although clearly positive for PCNA, had failed to incorporate BrdU (Figure S2C). This combined data suggested that BMI1-depleted cells had undergone an intraS-phase arrest. Similarly, primary human articular cartilage-derived (HAC) cultures exhibited coinciding reduction of BrdU-incorporation and differentiation-associated proliferative capacity in the absence of BMI1, independently confirming the TA-associated phenotype in PRC1-deficient cells (Figure 2D). Comparable to BMI1-depletion, PHC2-depletion diminished chondrogenic proliferation and increased S-phase accumulation (Figure S2D,E). Conversely, $m B m i 1$-cDNA overexpression produced a modestly but reproducibly enhanced TA phase (data not shown). The collective above data provides multiple independent lines of evidence for a general involvement of PRC1 in chondrogenesis-associated transit amplification.

A

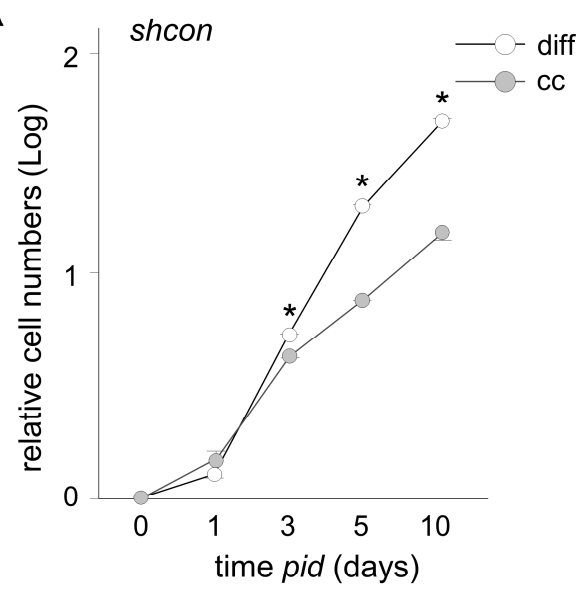

B

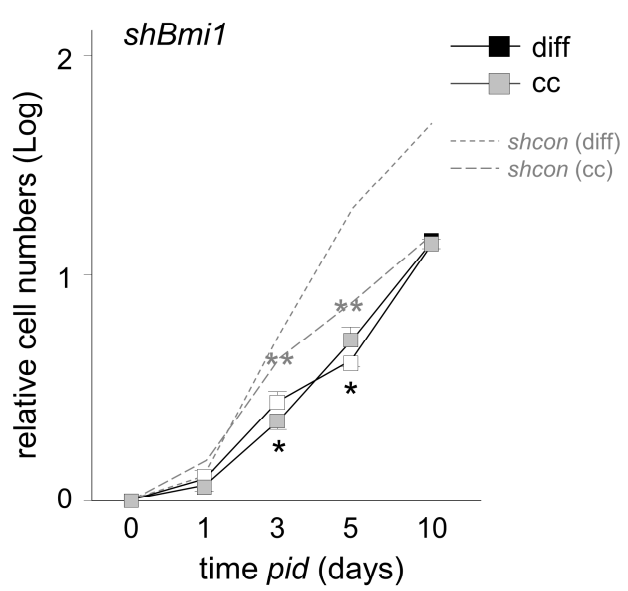

Figure 2. Cont. 


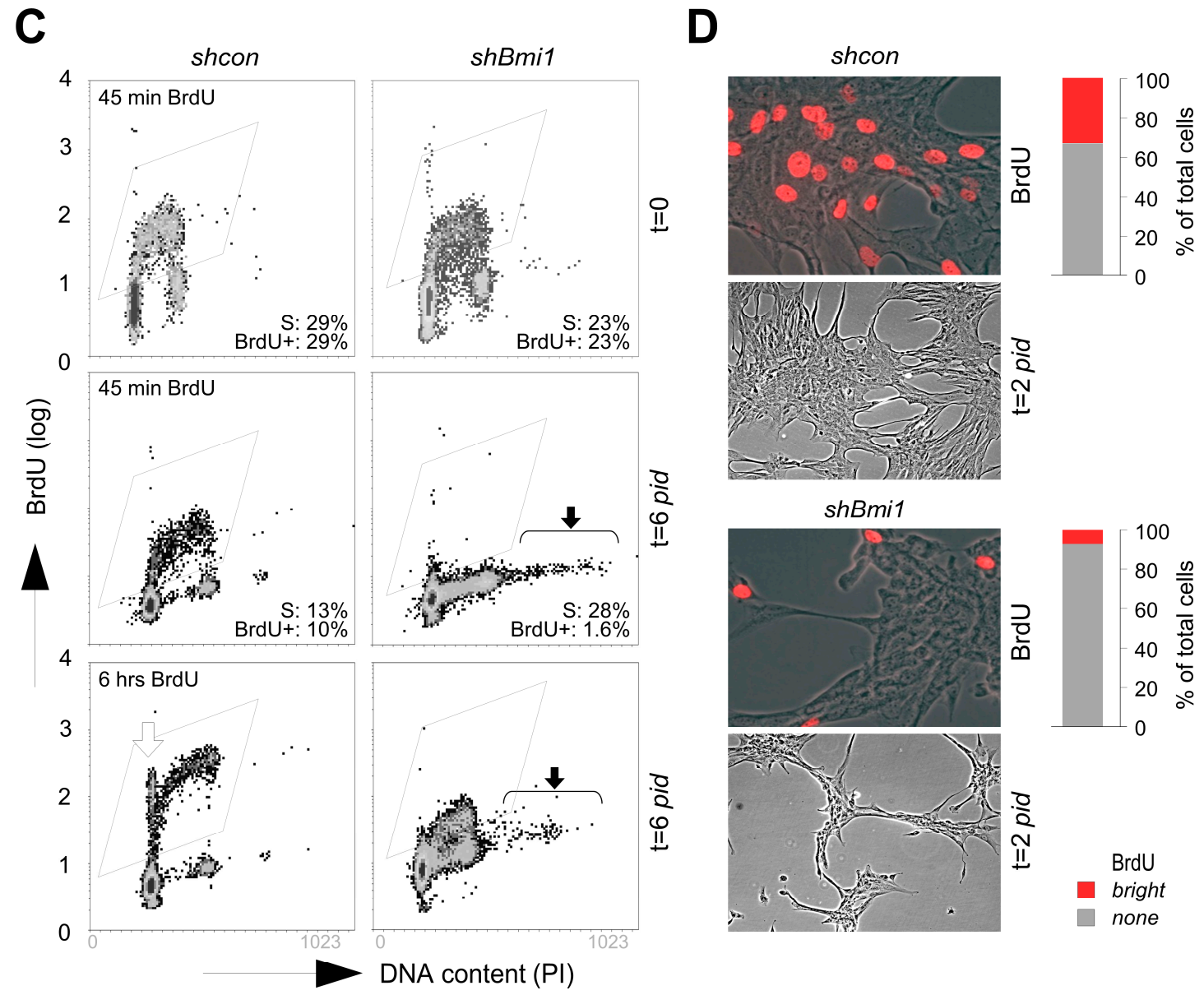

Figure 2. Loss of BMI1 elicits intraS-phase accumulation. Proliferation of shcon (A) and shBmi1 (B) ATDC5 cells under maintenance ( $c c$ ) and differentiation (diff) conditions; dashed curves (B) represent the "shcon (diff)" and "shcon (cc)" curves in (A) as indicated in inset. Data based on three independent parallel experiments; asterisks ( $\left.{ }^{*} ; \mathbf{A}, \mathbf{B}\right)$ : control versus differentiation conditions; $p<0.05 ;\left({ }^{* *} ; \mathbf{B}\right)$ "shcon $(c c)$ " versus "shBmi1 (cc)"; $p<0.05$. (C) Representative, corresponding experiments showing (C) de novo DNA replication at $\mathrm{t}=0$ and 6 days pid after $45 \mathrm{~min}$ (top \& middle panels) and $6 \mathrm{~h}$ (bottom panels) BrdU-incorporation in shcon (left panels) and shBmi1 (right panels) ATDC5 cells. Numbers in bottom right corner of each panel indicates the \% S-phase/BrdU-positive cells in these experiment; DNA content was measured by propidium-iodide (PI) staining (quantitative representation: cf. Figure S2B); white arrow marks BrdU-positive cells re-entering G1-phase; black arrows mark polyploid cells (shcon: $0.76 \% \pm 0.14$; shBmi1: $3.46 \% \pm 0.25$ at $\mathrm{t}=6$ days pid; $p<0.05)$ and $(\mathrm{D})$ de novo DNA replication in differentiating shcon and shBmi1 HAC cells and visualized by immunofluorescent (IF) detection of BrdU-incorporation; representative IF images (upper panels) were deliberately selected based on areas with near-equal cell density. Representative phase-contrast images (lower panels) reflect reduced overall cell proliferation. Quantification of IF data is depicted to the right of the IF images (legend at the bottom).

\subsection{BMI1-Deficiency Leads to Increased Replication-Associated DNA Damage during Transit Amplification}

IntraS-phase accumulation/arrest can be initiated as part of a DNA damage response (DDR) [28]. Stalled or damaged replication forks are known to coincide with double strand DNA breaks (DSB); the latter are detectable by enhanced local Ser139-phosphorylation on histone H2A.X (yH2A.X) by ATM, which signals DNA damage [29]. Combined, the intraS-phase arrest and coinciding diminished de novo DNA replication of BMI1-depleted ATDC5 cells suggested that PRC1 function supports differentiation-induced hyperproliferation through mechanism(s) that prevent intraS-phase checkpoint 
activation. To determine whether BMI1-depleted cells accumulate DNA damage during TA, nuclei were analyzed for the presence of DSB using immunofluorescence (IF). Under maintenance conditions, both control and shBmi1 ATDC5 cultures typically included some faintly yH2A.X-positive nuclei (Figure S3A); although we cannot formally rule out any activity of other PIKK family kinases, it is conceivable that the low yH2A.X signal related to normal local replication-associated DSB [30]. Increased DNA damage was observed in some experiments as early as $t=1$ day pid in shBMi1 cultures (vs. shcon; Figure S3B), whereas the yH2A.X signal had dramatically increased in BMI1-KD cultures at $\mathrm{t}$ $=6$ days pid (Figure 3A); at this stage, shBmi1 ATDC 5 cultures had accrued approximately $3-4 \times$ higher yH2A.X levels than differentiating shcon cultures (Figure 3B). DDR-mediated cell cycle arrest under BMI1-depleted conditions was confirmed by very weak/absent H3S10ph-staining in nearly all (>95\%) brightly positive yH2A.X nuclei (Figure S3C). Single Cell Gel Electrophoresis (SCGE/comet) analysis revealed significantly enhanced tail-moments in shBmil cultures (vs. shcon), independently confirming the presence of DSB (Figure 3C). Increased ATM-induced KAP1S824-phosphorylation, enhanced RAD51 and RPA70/chromatin-association in yH2A.X-positive nuclei during TA (Figure S3D-F) and upregulation of DNA damage and repair pathways (Table S1) were consistent with the initiation of DDR in BMI1-deficient cells. Similarly, also BMI1-depleted primary HAC cells showed elevated yH2A.X levels at $t=2$ days pid (Figure 3D and Figure S3G). Importantly, the above findings provide definite evidence for enhanced DDR in BMI1-depleted cells in response to induction of differentiation/proliferation and show that accumulation of DNA damage and intraS-phase arrest coincide during chondrogenic TA in the absence of BMI1.

A

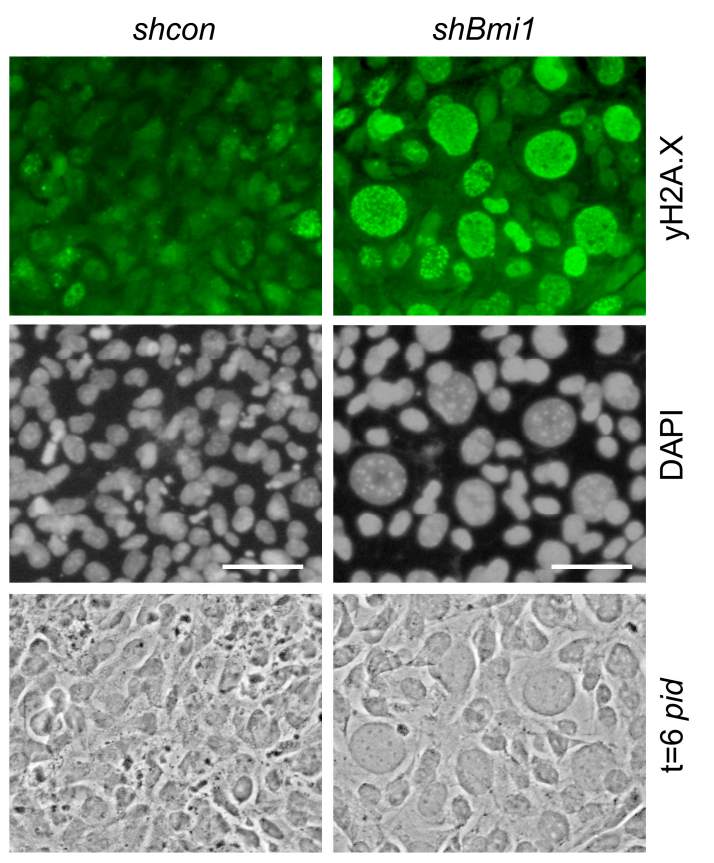

B

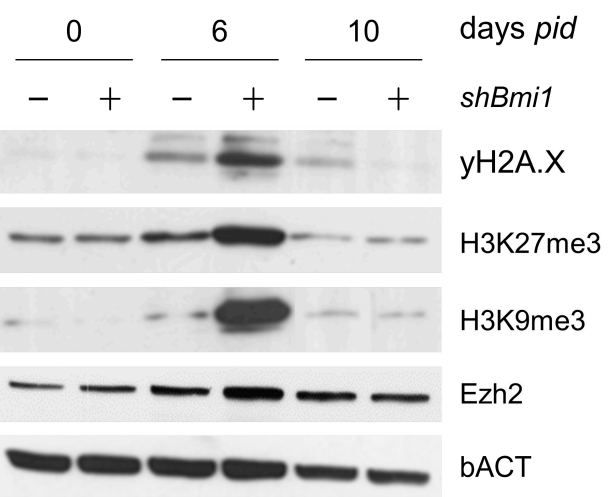

C
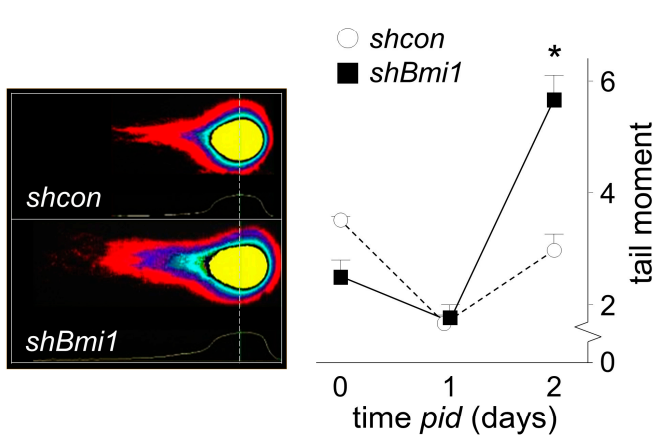

Figure 3. Cont. 

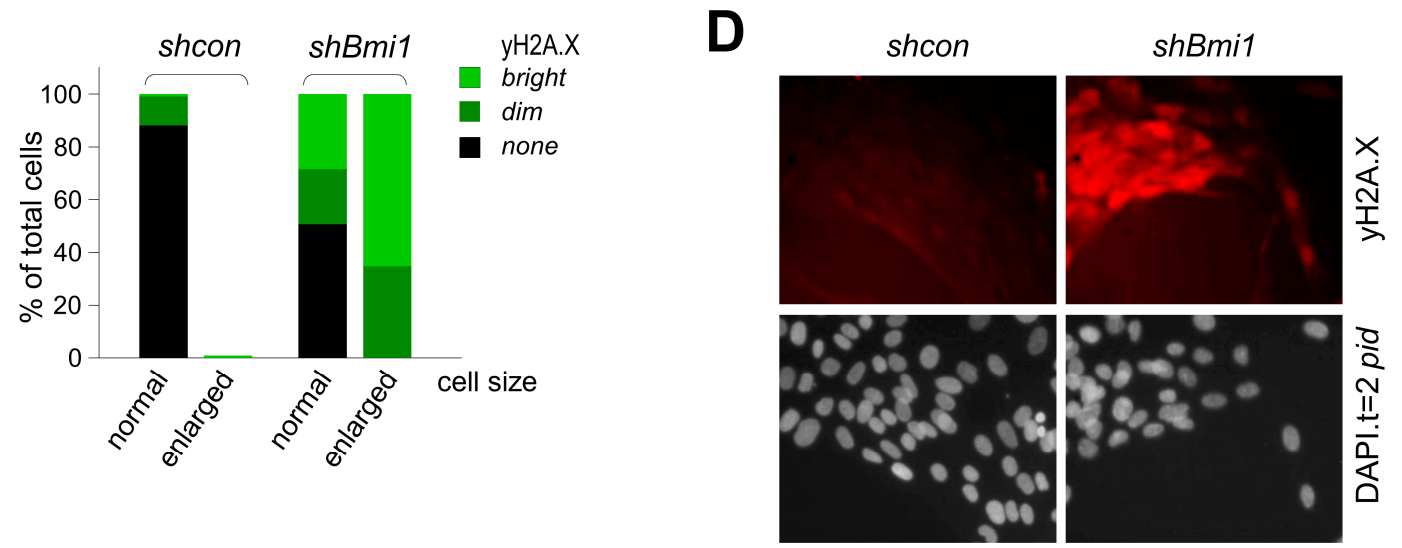

Figure 3. Activation of DNA damage response (DDR) in the absence of PRC1. (A) Representative IF images of yH2A.X staining in ATDC5 shcon and shBmil cells at $\mathrm{t}=6$ days pid (upper panels); corresponding DAPI and phase-contrast images (middle and lower panels), showing nuclei and whole cells, respectively; scale bar: $10 \mu \mathrm{m}$. Quantification of immunofluorescence (IF) data is depicted below the IF images; $23 \%$ of shBmi1 cells displayed an enlarged flat cell phenotype; all enlarged cells were positive for yH2A.X; (B) Comparative IB analysis of total cellular histone modifications yH2A.X, H3K27me3 and H3K9me3 levels in shcon and shBmi1 cells at indicated time-points pid; (C) Double strand breaks (DSB) in differentiating shcon and shBmi1 cells were determined by SCGE assay (neutral comet assay); representative images of $s h B m i 1$ and shcon comets at $\mathrm{t}=2$ days pid (left panel); quantification of tail moments (right panel; Asterisk (*): $p<0.001$ ); (D) Representative IF images showing yH2A.X staining in shcon and shBmi1 HAC (human articular chondrocytes) cells at $\mathrm{t}=6$ days pid (upper panels); corresponding DAPI images (lower panel). For quantification of IF data, see: Figure S3G.

\subsection{H3K27me3 Is not a Major Determinant of Transcriptional Repression during Differentiation}

We next determined the effect of BMI1-depletion on global chondrogenic transcriptional programming, by comparing gene expression profiles in control and BMI1-KD cultures between successive time-points throughout differentiation. Whole transcriptome analysis in control cells revealed that chondrogenesis-associated transcriptional programming became overt at $\mathrm{t}=1$ day pid: beyond this time-point, loss of data-point clustering to the identity line indicated substantial change in the overall gene expression profiles (Figure 4A). Importantly, this transcriptomic data independently confirmed that differentiation-associated transcriptional programming coincided with TA. Of note, beyond $t=6$ days pid (i.e., days 6 to 15), chondrogenic profiles were stably maintained (Figure 4A). In BMI1-KD cultures, data-point scattering between successive time-points was noticeable from $t=8 \mathrm{~h}$ pid onwards, reflecting early transcriptional dysregulation in the absence of BMI1 (Figure 4A). Although speculative, the observed restriction of transcriptome complexity at later time points (10 to 15 days) pid in shcon cultures may relate to reduced proliferative capacity. When examined at the level of individual genes, progressive differential gene expression between control and BMI1-KD cultures was prominently visible between $t=1$ and 6 days pid: over one-third of mRNAs was deregulated at least 1.2-fold in BMI1-KD cultures (Figure S4A). Of note, loss of BMI1 resulted in comparable percentages up and down-regulated mRNAs (Figure S4B). Retrospective analysis of the most deregulated reporters at $\mathrm{t}=6$ days pid revealed that misexpression of these reporters was already observed in BMI1-deficient cultures early into differentiation, with genes mapping both to relevant and non-relevant pathways for chondrogenesis (Table S2; Figure 4B). Independently, cluster analysis of more than two-fold deregulated genes at $\mathrm{t}=6$ days pid, distinguished additional reporter sets that showed sustained transcriptional repression in BMI1-deficient cultures throughout chondrogenic differentiation (Figure S4C,D). This data supports the idea that loss of a transcriptional repressor (i.e., BMI1) did not exclusively induce gene activity. 
A

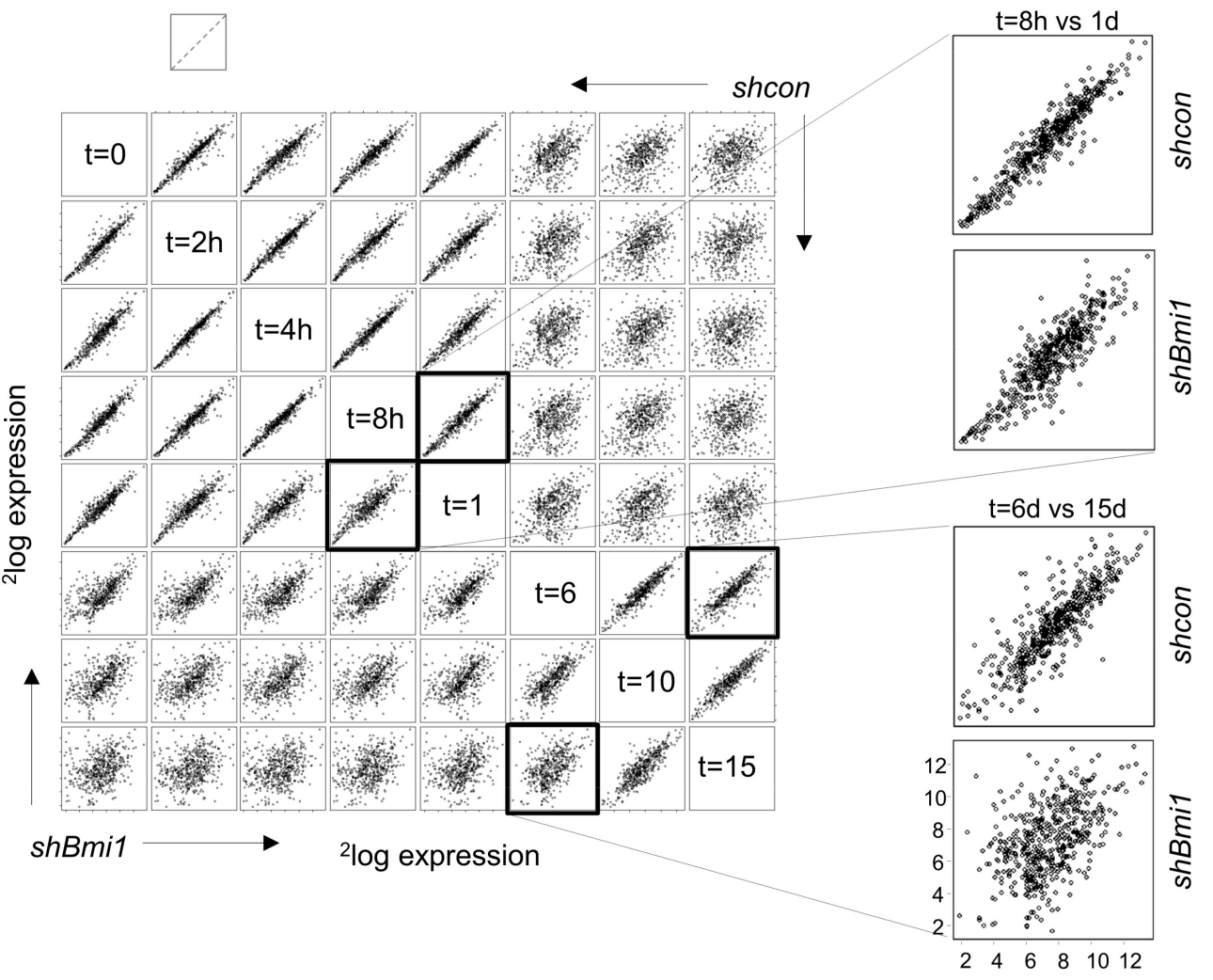

B

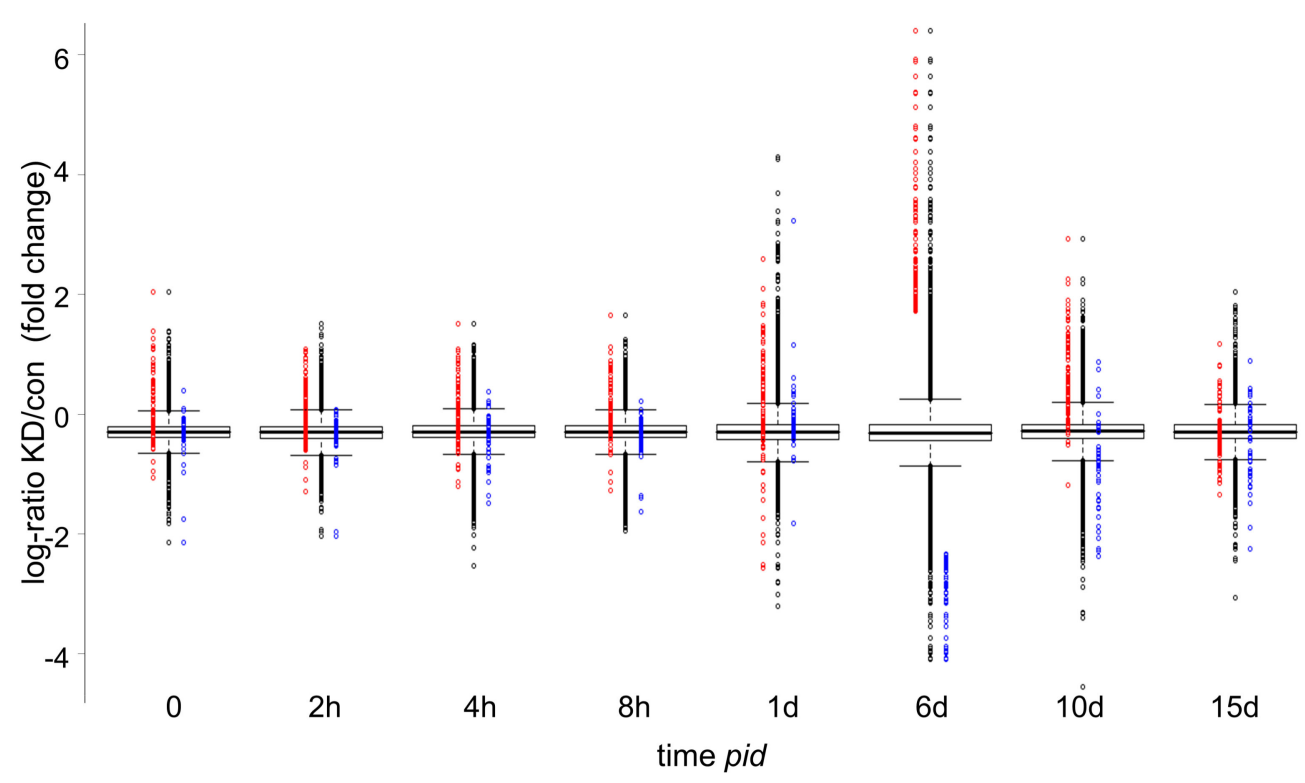

Figure 4. Abnormal transcriptional responses in BMI1-deficient cells. (A) Matrix display of scatter-plots of ${ }^{2} \log$ expression values for all time-points relative to each other in shcon (upper right half) and shBmi1 cells (lower left half), based on reporters (i.e., mRNAs) fulfilling $p<0.05$, absolute FC (fold change) $\geq 2$, expression $>{ }^{2} \log (100)$ in either group, at $\mathrm{t}=1$ or 6 days pid. Perfect fit to the identity line (see: dashed grey diagonal at the top of (A)) would indicate absence of differential expression between time-points). Insets: (upper) $\mathrm{t}=8 \mathrm{~h}$ vs. 1 day and (lower) $\mathrm{t}=6$ days vs. 15 days pid. (B) FC for all reporters. Box-plots of shcon vs. shBmi1 log-ratios for all reporters (regardless of expression level, fold change or significance) for each time point in differentiation; colors red or blue retrospectively mark genes with a $\geq 4$ FC up (red; $\mathrm{n}=106$ ) or down (blue; $\mathrm{n}=49$ ) at $\mathrm{t}=6$ days pid; box represents 1 st-3rd quartiles; whiskers set at $1.5 \times$ interquartile distance. 
As PRC-mediated transcriptional regulation involves histone $\mathrm{H} 3$ lysine (K) 27 trimethylation (H3K27me3), we examined global H3K27me3-marking in relation to transcriptional silencing in shcon cells and whether this had changed in shBmi1 cells. Global H3K27me3 levels had increased approximately two-fold in control cells by $\mathrm{t}=6$ days pid, whereas in BMI1-deficient intraS-phase-arrested cells, chromatin-associated H3K27me3 had accumulated to substantially higher levels; this increase paralleled enhanced levels the H3K27me3 methyltransferase EZH2 (cf. Figure 3B). Also, H3K9me3 levels were higher in shBmil cultures at $\mathrm{t}=6$ days pid; the increase of both trimethyl marks correlated with elevated yH2A. $X$ during failed differentiation (cf. Figure 3B). To determine whether aberrant transcriptional regulation correlated with abnormal Polycomb-associated histone marking in BMI1-deficient cells, epigenome-wide H3K27me3-profiles of shcon and of shBmi1 cells were compared at $\mathrm{t}=0$ and 3 days pid using chromatin-immunoprecipitation/deep-sequencing (ChIP-seq). As demonstrated above, at 3 days pid, transcriptional reprogramming coincided with TA and DSB featured prominently in shBmil cultures. We found that pre-chondrogenic H3K27me3-enrichment (i.e., at $\mathrm{t}=0$ in shcon cells) within specified genic regions (i.e., promoter, TSS, gene-body) closely correlated to low/absent transcriptional activity (Figure S5D), in keeping with published data in various other systems [31-33]. Despite the substantial gene expression-reprogramming during normal (shcon) chondrogenic TA, overall genic/intergenic H3K27me3-distribution remained largely unaltered at $\mathrm{t}=3$ days pid (Figure S5E). Surprisingly, in BMI1-KD cultures, the overall correlation between genic H3K27me3-marking and low/absent gene expression was sustained and relative genome-wide H3K27me3-distribution did not significantly change, despite increased overall H3K27me3 levels (Figure S5D,E). To probe for specific effects of BMI1-depletion on gene expression in relation to changes in H3K27me3-marking, we analyzed gene expression changes during chondrogenic TA, at loci that had gained or lost H3K27me3-decoration during early chondrogenic differentiation (i.e., $\mathrm{t}=0$ vs. 3 days pid), or that had remained stably decorated or non-decorated. Under normal chondrogenic conditions (shcon) the range of fold-changed gene expression had increased in all H3K27me3-marked and unmarked categories during chondrogenic TA (Figure S5F). In contrast, the extent of fold-changed gene expression variation in BMI1-KD cells at 6 days pid was comparable to that at $\mathrm{t}=0$, consistent with failed differentiation-associated transcriptome reprogramming (Figure S5F). Of note: this occurred regardless of H3K27me3 marking, indicating that H3K27me3 per se is not a major determinant of transcriptional repression during chondrogenesis and that the functional connection between H3K27me3 and transcriptional regulation was lost in the absence of BMI1. Consistent with its multidirectional effects on transcription deregulation (i.e., up and down-regulation; cf. Figure 4), BMI1-depletion affected H3K27me3-marked and unmarked loci (reference: $\mathrm{t}=0$ /shcon) alike during chondrogenic TA (Figure 5A and Figure S5G). Expression profile analysis as a function of time within two relevant gene networks representing chondrogenesis and cell proliferation (Tables S3 and S4), revealed that overall gene activity of these limited markers sets remained largely unaltered between shcon and shBmi1 cells (Figure 5B and Figure $\mathrm{S} 5 \mathrm{H}$ ), irrespective of gain, loss or stable H3K27me3-enrichment. The most prominent variation in gene expression in the 'Cell cycle' network during TA (i.e., between $t=1$ and 6 days pid), occurred among non-H3K27me3 enriched markers (Figure $\mathrm{S5H}$ ), consistent with checkpoint activation in the absence of BMI1. The above combined data supports the notion that genic H3K27me3-marking alone is not sufficient for transcriptional repression during differentiation and that the massive transcriptional deregulation in BMI1-deficient cells cannot be solely explained by loss of PRC1-mediated transcriptional repression. 
A

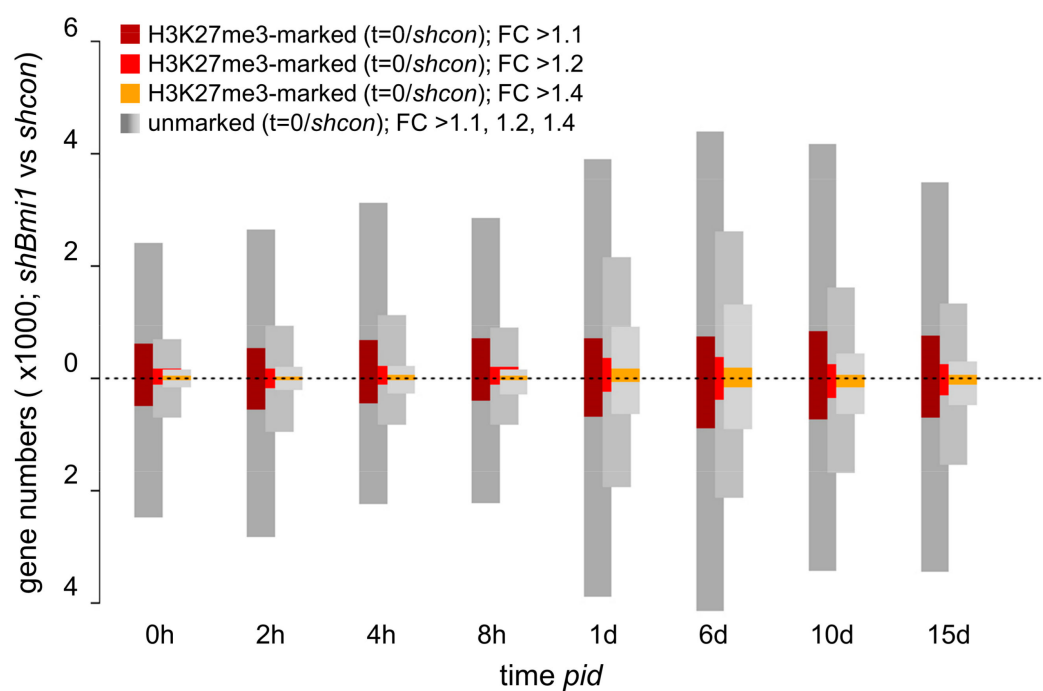

B

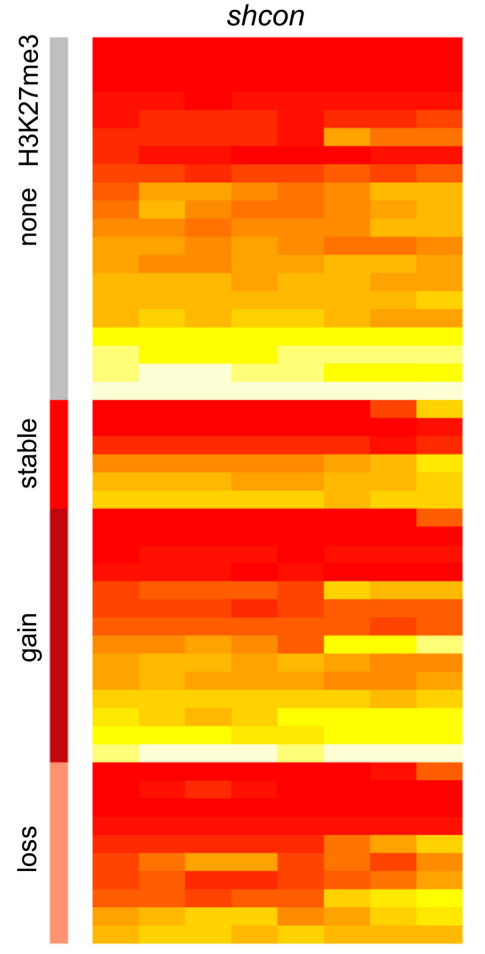

Oh $2 \mathrm{~h} 4 \mathrm{~h} 8 \mathrm{~h} 1 \mathrm{~d} 6 \mathrm{~d} 10 \mathrm{~d} 15 \mathrm{~d}$

\section{shBmi1}

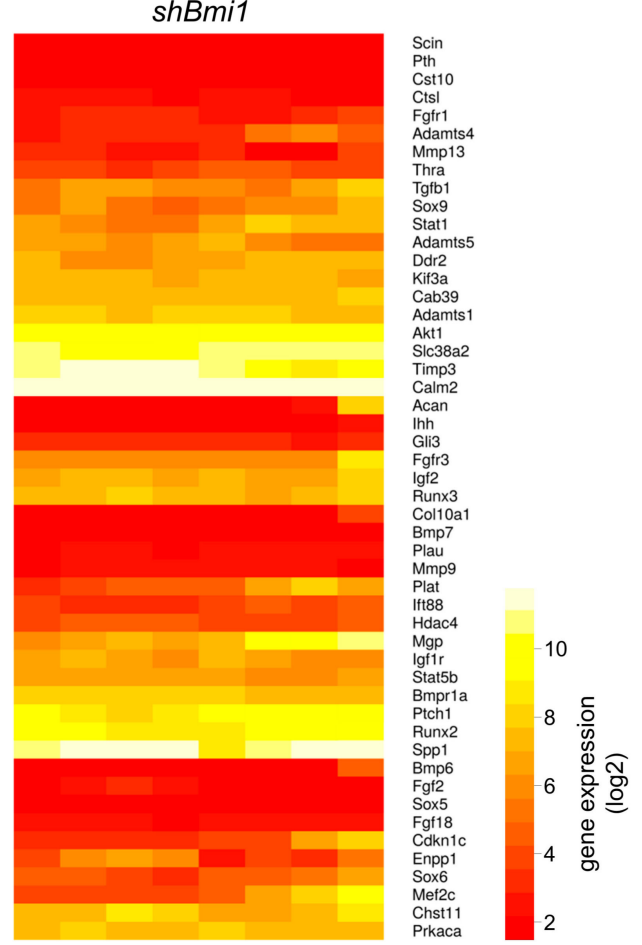

Oh $2 \mathrm{~h} 4 \mathrm{~h} 8 \mathrm{~h} 1 \mathrm{~d} 6 \mathrm{~d} 10 \mathrm{~d} 15 \mathrm{~d}$

time pid

Figure 5. H3K27me3-independent transcriptional deregulation in the absence of BMI1. (A) Altered expression between $t=0$ and 6 days pid is equally distributed over originally H3K27me3-enriched and non-enriched genes (i.e., in BMI1-proficient shcon cultures at $t=0$ ). Bar graphs show the number of genes that are up- or down-regulated (above and below $x$-axis respectively) between $t=0$ and 6 days pid, divided in H3K27me3-enriched and unmarked genes for three arbitrarily defined classes, based on gene expression fold change (FC) between shBmi1 and shcon (FC > 1.1, 1.2 or 1.4, respectively). Analyses was based on reporters with expression $>\log 2(100)$. (B) Heatmap of representative marker expression for 'Endochondral ossification' (cf. Table S3) for shcon (left panel) and shBmi1 (right panel) ATDC5 cells. H3K27me3-enrichment status was defined based on ChIP-seq data comparison between $\mathrm{t}=0$ and 3 days pid in the shcon experiment: unmarked (none), stably marked (stable) or loci that had acquired (gain) or lost (loss) H3K27me3-marking (see Methods section for further definition of the marker set H3K27me3). 


\subsection{Abnormal TOP2A Cleavable-Complex Processing in PRC1-Deficient Cells Causes Double Strand DNA Breaks}

PRC1 is involved in at least three major DNA-templated processes relevant during differentiation and TA: transcription, replication and repair, all of which are subject to dynamic chromatin structure modulation. Topoisomerases are central to all three chromatin-based processes [34,35]. Relevantly, PRC proteins were reported to reside in close proximity to the DNA-polymerase complex (DPOL) during replication and to associate with topoisomerases and native DNA during S-phase in Drosophila embryos and murine embryonic fibroblasts [36-38]. BMI1/RING1 was identified as a major E3-ligase complex targeting topoisomerase 2 alpha (TOP2 $\alpha$ ) cleavable complexes in an siRNA-based screen aimed at increasing toxicity of TOP2-directed drugs in cancer therapy [39]. The relevance of BMI1 as a potential TOP $2 \alpha$ E3 ligase in a normal developmental biological context has, however, not been established. Failure to undergo transcriptional reprogramming and TA in BMI1-depleted cultures suggested defective coordination of multiple chromatin-based activities early during chondrogenesis. Therefore, we next pursued the possibility that loss of nuclear coordination of transcription and replication was the cause for DNA damage and DDR in BMI1-KD cells. To this end, we first aimed to establish a functional interaction between PRC1 and TOP $2 \alpha$ in ATDC5 cells. In good agreement with the reported direct functional connection between BMI1/RING1 and TOP2 $\alpha$, we found that loss or gain of BMI1 in ATDC5 cells increased or reduced sensitivity for the Topo-poison etoposide, respectively (Figure S6A). Independently, PHC2 or RNF2-depletion reduced cell survival in the presence of etoposide, pointing to a general involvement of intact PRC1 in controlling TOP2 $\alpha$ function (Figure S6A). DNA replication and transcription machineries both utilize topoisomerase activity and hence introduce catalyzed DSB. Subsequent proteolytic removal of TOP2A-cleavable complexes is required to expose and repair TOP $2 \alpha$-protected DSB as well as to ensure progression of DNA and/or RNA synthesis [40]. Lack of a putative TOP2 $\alpha$-directed PRC1 E3-ligase activity predicted an increased presence of covalently chromatin-bound TOP $2 \alpha$ complexes during TA in the chromatin-bound protein fraction of BMI1-deficient cells. Failure to detect any quantitative difference in TOP $2 \alpha$-DNA intermediates at $t=0$ (vs. shcon; Figure 5A) was in good agreement with the limited effect of BMI1-depletion on proliferation in non-differentiating cultures (cf. Figure 2 and Figure S2). Whereas in shcon cells total (soluble) cellular TOP2 $\alpha$ was reduced under differentiating (vs. non-differentiating) conditions, total TOP2 $\alpha$ remained high in shBmi1 (vs. shcon) cells under differentiation conditions (Figure 6A; cf. soluble fractions). Relevantly and in clear contrast to non-differentiated ATDC5 cells, TOP $2 \alpha /$ chromatin-association was markedly increased in BMI1-depleted (vs. control) cells at $\mathrm{t}=6$ days pid (Figure 6A). Increased presence of TOP $2 \alpha$ predicted the presence of DSB at sites of de novo DNA synthesis. Indeed, co-staining for newly incorporated BrdU and yH2A.X showed that all BdrU-labeled nuclei were also positive for $\mathrm{yH} 2 \mathrm{~A}$. $\mathrm{X}$ and, moreover, that nuclear foci of de novo DNA synthesis overlapped perfectly with damaged DNA (Figure 6B). These collective chromatin-based analyses are in good agreement with the reported PRC1 E3-ligase activity toward TOP2 $\alpha$ and support a biological role for this functional connection during chondrogenesis: failure to remove TOP $2 \alpha$ in the absence of PRC1 results in local DNA damage. The observation that expression of all three evaluated PRC1 members is elevated under normal differentiating conditions in vivo and in vitro (cf. Figure S1A) is congruent with the idea the chondrogenic TA phase requires PRC1. 
A
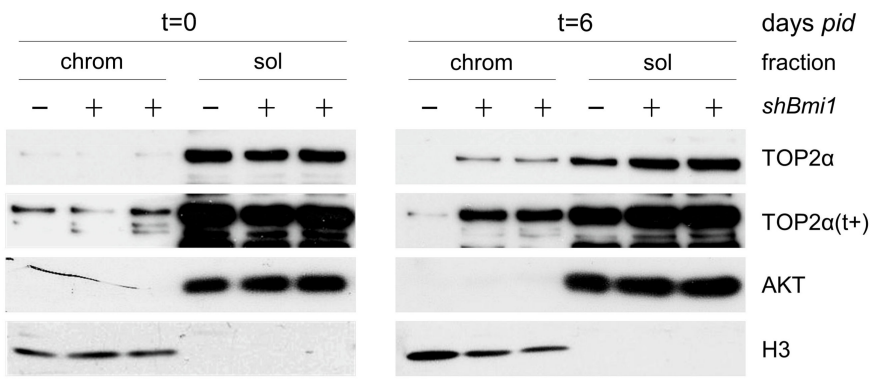

B
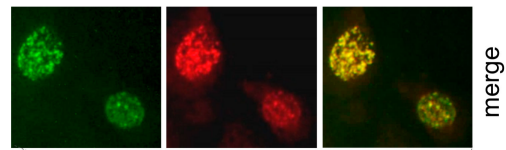

shcon

shBmi1

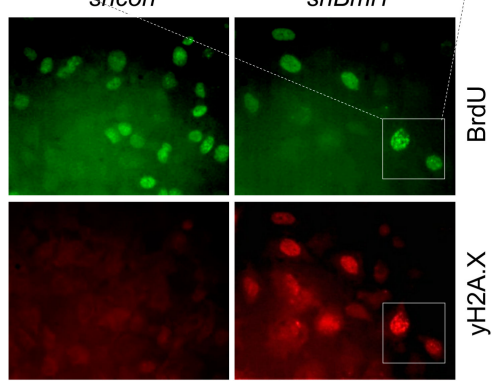

$\mathrm{t}=3$ pid

D

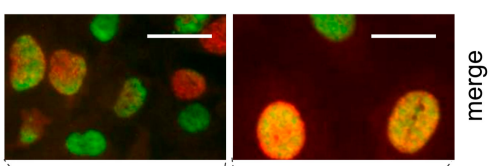

shcon

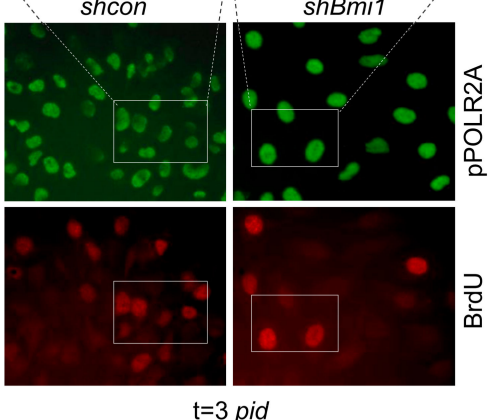

C

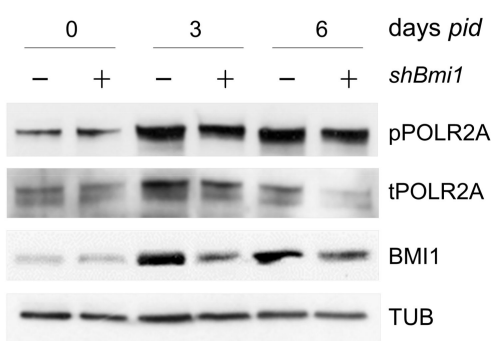

E

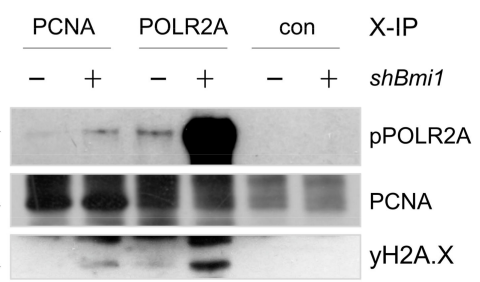

Figure 6. Abnormal coordination of DNA-templated activity in BMI1-depleted cells. (A) Detection of covalently chromatin-bound topoisomerase 2 alpha (TOP2 $\alpha)$ in the presence $(-\operatorname{shBmi1})$ or absence of BMI1 (+ shBmi1); duplicate shBmi1 (+) samples represent two independent parallel experiments; to enable comparative quantitative assessment cytoplasmic and chromatin-bound fractions were proportionally loaded; all samples were loaded on the same gel. Separation of chromatin-bound (chrom) TOP2 $\alpha$ fraction and soluble (sol; cyto + nucleoplasmic) TOP2 $\alpha$ fractions was validated by histone $\mathrm{H} 3$ and AKT detection, respectively; $(\mathrm{t}+$ ) marks longer appositions; (B) Representative image showing combined IF detection of local damage response (yH2A.X) and de novo DNA replication (BrdU; 10 min BrdU pulse) in shBmi1 ATDC5 at $\mathrm{t}=3$ days pid; (C) Expression analysis (IB) of total cellular POLR2A (tPOLR2A) versus phosphorylated POLR2A (pPOLR2A) in shcon and shBmi1 cells at $\mathrm{t}=0,3$ and 6 days pid. For quantification of protein levels, see Figure S6C; (D) Representative IF image showing combined detection of phosphorylated POLR2A ( $p P O L R 2 A)$ and de novo DNA replication (BrdU; 10 min BrdU pulse) in shBmi1 ATDC5 at $\mathrm{t}=3$ days pid; scale bar: $5 \mu \mathrm{m}$. For quantification of IF data, see Figure S6E; (E) Cross-linking immunoprecipitation (XIP)-based assessment of colocalization of pPOLR2A and PCNA with damaged DNA at $\mathrm{t}=6$ days pid. XIP was carried out using indicated antisera on chromatin fractions of $\pm 2000-5000 \mathrm{bp}$. 


\subsection{Increased POLR2 Phosphorylation and Stalled Transcription Forks in BMI1-Depleted Cells}

The enhanced presence of TOP2 $\alpha$ on chromatin in BMI1-depleted cells during a period of intense chromatin usage (i.e., combined chondrogenic transcriptional programming and increased proliferation), is predicted to increase the risk of transcription forks and stalled replication forks collision. Relevantly, PRC have been suggested to bind and disassemble RNA polymerase 2 holo-complex [41]. Accumulation of stalled transcription machineries, in turn, is expected to enhance DSB and DDR during chondrogenic TA. We therefore set out to find evidence for transcription fork stalling in BMI1-depleted cells. Transcriptional stalling is associated with hyperphosphorylation of the largest subunit RPB1 of the RNA polymerase 2 holo-complex (pRPB1, henceforward referred to as pPOLR2A) [42]. POLR2A hyperphosphorylation signals increased proteolytic removal of arrested POLR2A complexes to bypass stalled transcription and repair transcription-associated DNA breaks $[43,44]$. Phosphorylated POLR2A (pPOLR2A) had markedly increased between $t=0$ and 3 days pid, both in shcon and in shBmi1 cells and pPOLR2A remained high throughout TA (Figure 6C). The reduction of total POLR2A (tPOLR2A) in shBmil cells at $\mathrm{t}=6$ days pid significantly increased the pPOLR2A/tPOLR2A ratio in BMI1-deficient nuclei (Figure 6C and Figure S6C). IF analysis revealed that, although overall POLR2A phosphorylation was higher in shBmi1 than in shcon cultures, activation of DDR (i.e., high levels of $\mathrm{yH} 2 \mathrm{~A} . \mathrm{X}$ ) correlated with severely reduced pPOLR2A detection at the level of individual cells (Figure S6D), further strengthening the connection between DNA damage and POLR2A degradation. To study a regulatory relationship between PRC1 and de novo DNA replication and nuclear transcriptional activity, S-phase cells were allowed to incorporate BrdU and were simultaneously stained for pPOLR2A. The majority of control cells displayed a seemingly non-uniform nuclear distribution for active transcription at $\mathrm{t}=3$ days pid, whereas shBmi1 cells consistently showed a high, mostly uniform staining for pPOLR2A (Figure 6D and Figure S6E). Closer inspection of the IF images learned that especially the BrdU-bright shcon cells showed non-uniform very weak pPOLR2A staining and, vice versa, that pPOLR2A-bright shcon cells were typically BrdU-dim (Figure 6D and Figure S6E). In sharp contrast, this apparent inverse correlation between nuclear pPOLR2A and BrdU staining was completely lost in BMI1-KD cells: all BrdU-bright cells were pPOLR2A-bright as well (Figure 6D and Figure S6E). Conversely, not all shBmi1 PCNA-bright cells had incorporated BrdU, consistent with intraS-phase arrest. Of note, BMI1-depleted cultures showed substantially increased Geminin (GMNN)/chromatin association, a known PRC1 E3-ligase target (Figure S6F) [45,46]. GMNN is involved in DNA replication and gene transcription, the latter in concert with PRC1 $[45,47,48]$. The above combined data strongly corroborates the notion that PRC1-mediated regulatory aspects of DNA transcription and de novo DNA replication are lost during early chondrogenesis in the absence of BMI1.

Thus far our collective analyses suggested that loss of regulation of DNA replication and DNA transcription in the absence of BMI1 may be related to increased replication and/or transcription fork collision and stalling, resulting in DSB and enhanced DDR in S-phase cells during chondrogenic. This idea predicted that replication machineries and transcription complexes may be positioned in each other's vicinity more frequently in BMI1-deficient cells and that this correlates with increased DNA damage. To this end, we used an adapted chromatin cross-linking immunoprecipitation (X-IP) approach that allowed examination of chromatin fragments spanning several thousand (2000-5000) of base pairs; these chromatin fragments were analyzed for concurrence of PCNA (DNA replication machinery), pPOLR2A (DNA transcription machinery) and DSB (yH2A.X) on such chromatin fragments. Relevantly, PCNA IP co-precipitated pPOLR2A on chromatin fragments from BMI1-KD extracts only (Figure 6E); both PCNA and pPOLR2A co-precipitated yH2A.X-positive chromatin, again only in BMI1-KD cells only (Figure 6E). These findings support the notion that DNA damage results from enhanced relative proximity and/or collision of replication and transcription machineries in the absence of functional BMI1. 


\subsection{BMI1 Prevents Premature Replication-Associated Senescence during Chondrogenesis}

Several observations, including DDR and intraS-phase arrest, suggested that BMI1-depleted ATDC 5 cells may have undergone a senescence-like response (SLR) during defective TA/differentiation. Consistent with SLR, BMI1 and RNF2-deficient cell cultures contained more cells displaying large/flat cell morphology and increased polyploidy (Figure 2A, Figure 3A and Figure S7A). In addition, murine ATDC5 and primary HAC cells showed increased nuclear $\mathrm{H} 3 \mathrm{~K} 9 \mathrm{me} 3$ accumulation in the absence of BMI1 (cf. Figure 3B and Figure S5B,C), an epigenomic feature associated with cellular senescence [49]. In further corroboration of SLR in BMI1-KD cultures, several SMS/SASP (senescence-messaging secretome/senescence-associated secretory phenotype) indicators (e.g., Il-6, Ccl5, Cxcl10; [50,51]) showed an exaggerated response in the absence of BMI1 between $t=1$ and 6 days pid (Figure S7B). Loss of PRC1 function triggers premature senescence in several cultured cell types through transcriptional activation of the $C d k n 2 a /$ Ink $4 a$ locus [10]. It is currently neither known whether premature senescence features in (null)mutant PRC1-induced skeletal phenotypes nor whether $C d k n 2 a / \operatorname{Ink} 4 a$ is implicated at the molecular level. The finding that self-renewal of BMI1-deficient neuronal stem cells (NSC), is dependent on $C d k n 1 a / p 21^{C i p 1 / W a f 11}$ instead of $C d k n 2 / I n k 4 a$, supports the existence of multiple lineage specific PRC-dependent control mechanisms in self-renewal and/or differentiation-associated proliferation and is supported by other studies [5,52]. We first examined the ATDC5 model for an involvement of $C d k n 2 a / I n k 4 a$ in SLR. Of relevance, important checkpoints, e.g., contact inhibition and proliferative arrest after ionizing radiation, were found to be intact in non-differentiating ATDC5 [53]; (F.S. unpublished observations). Although expression profiles of several cell cycle inhibitors were altered (e.g., $\left.C d k n 1 b / p 27^{K i p 1}, C d k n 2 d / p 19\right)$, the $C d k n 2 a / I n k 4 a$ expression profile remained unchanged in BMI1-KD cultures compared to control cultures during chondrogenesis (Figure S7B), suggesting $C d k n 2 /$ Ink $4 a$ may not be directly involved in the SLR reported here.

Endochondral differentiation terminates in chondrocyte hypertrophy in the hypertrophic zone (HZ; cf. Figure 1A); here chondrocytes are replaced by invading osteoclasts and osteoblasts and calcification of the extra-cellular matrix ultimately leads to the formation of calcified bone [20]. We next explored the possibility that chondrocyte hypertrophy may represent an in vivo manifestation of cellular senescence. Expression analysis of normal ATDC5 chondrogenic differentiation in vitro revealed that numerous SMS markers were subject to dynamic regulation during TA (Figure S7B), suggesting an analogy to SMS marker induction in the context of oncogene-induced senescence $[50,51]$. Senescent cells typically express the senescence-associated beta galactosidase 1 (SA- $\beta$ GAL/GLB1) protein [54]. Remarkably, induction of SA- $\beta$ GAL activity was part of normal chondrogenesis in all chondrogenic models we examined (Figure S7C-E). As the hypertrophic chondrocyte phenotype may be causally linked to hyperproliferation in vivo, we reasoned that endochondral differentiation terminates in a senescence-like condition and that SA- $\beta$ GAL-positive cells should thus be detectable adjacent to growth plates in elongating bones. Indeed, prominent SA- $\beta$ GAL activity overlapping the $\mathrm{PZ} / \mathrm{HZ}$ was detected in growing murine long bones and in human and murine ribs (Figure 7A,B and Figure S7F). Of note: SA- $\beta$ GAL marked the proliferative and hypertrophic zones but not the low-proliferative isogenic groups in human hyaline rib cartilage (Figure 7A); this finding further supported a close association of enhanced cell proliferation and SA- $\beta$ GAL-positive hypertrophy during normal endochondral bone formation. 


\section{A}

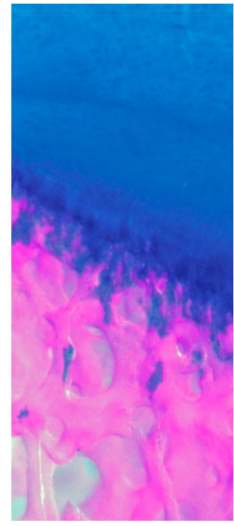

alcBl/aznRd

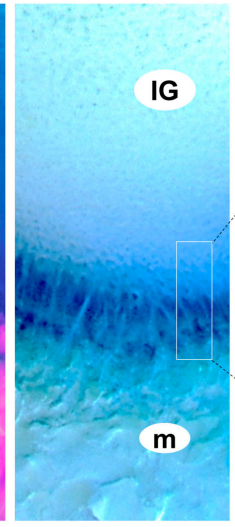

SA-BGAL

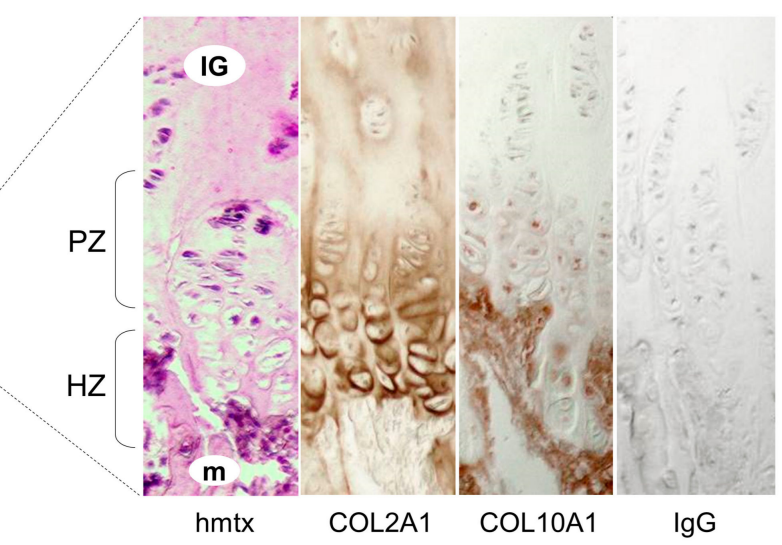

COL2A1

COL10A1

IgG

\section{B}

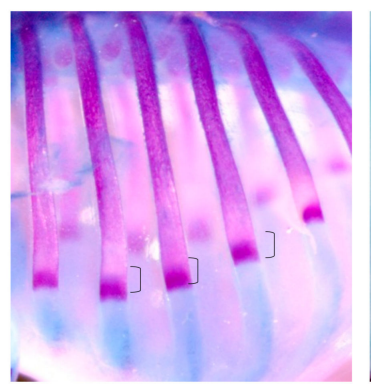

aznRd; SA-BGAL

\section{C}

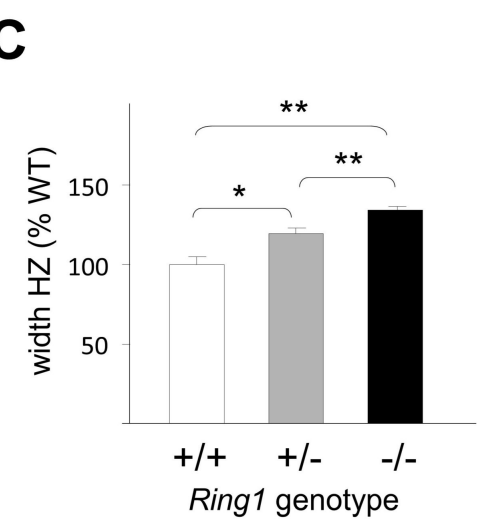

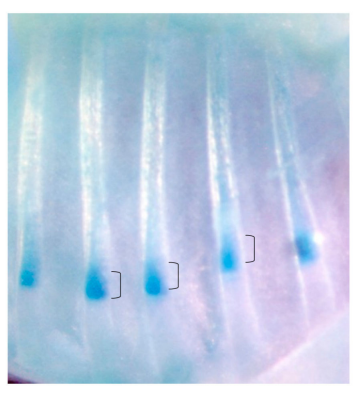

SA- $\beta G A L$

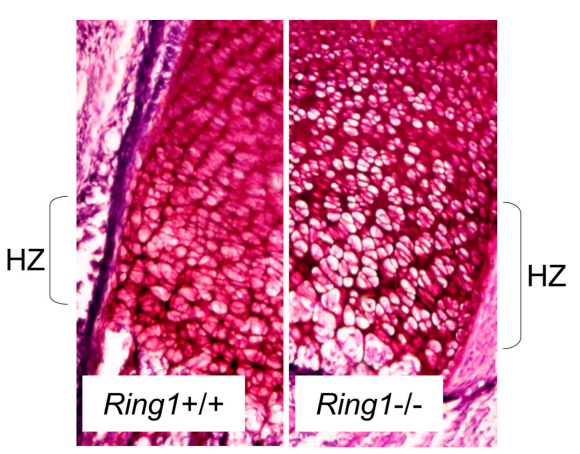

Figure 7. Normal and premature senescence in chondrogenesis. (A) Active growth plates in human ribs; combined alcian blue (alcBl; cartilage proteoglycan marker) and alizarin red ( $a z n R D$; calcified bone marker) or SA- $\beta$ GAL staining only (left panels); (right panels) IH-staining for COL2A1 and COL10A1 (cf. Figure 1A); negative control: IgG. Hematoxylin (hmtx) image shown at left side. PZ/HZ: proliferative/hypertrophic zones; IG: isogenous groups; $m$ : marrow spaces. 30x magnification; (B) SA- $\beta$ GAL detection in growth plates of normal murine ribcages $p p 1$ (postpartum day 1); (left panel) combination staining of SA- $\beta$ GAL and alizarin red $(a z n R d)$, (right panel) SA- $\beta$ GAL staining only; brackets mark PZ/HZ zones; (C) Quantitation of HZ-width measurements (left panel) in femurs of Ring1-/ - (homozygote genetic knock-out) versus Ring1+/ - (heterozygote) and +/ + (wild type) pp1 mice. Asterisks indicate $p$-values: ${ }^{*} p<0.05 ;{ }^{* *} p<0.001$; (right panel) representative images of femur growth plates of Ring1WT and Ring1KO pp7 mice (Sirius-red staining); brackets mark HZ. 
Numerous single PRC1 genetic null-mutant models display defective skeletogenesis and stunted growth; some compound-PRC1 mutant mice reveal gross skeletal abnormalities including shortened upper extremities [22-26]. Given the prominent PRC1 protein expression in growth plates (cf. Figure 1) and the SLR induced by loss of PRC1 function in vitro, we predicted that SLR also occurs in vivo and should become manifest as increased HZ-width in PRC1-deficient mice. To this end we probed growth plates of newborn PRC1-mutant animals for the occurrence of premature senescence (i.e., increased numbers of hypertrophic cells). In keeping with this, homozygous Ring1 null-mutant $(-/-)$ newborn mice, which display a comparatively strong penetration of the PRC1 mutation-related skeletal phenotype [26], revealed a significantly widened HZ compared to heterozygous $(+/-; 19.8 \%)$ and wild type animals $(+/+; 34.0 \%$; Figure $7 \mathrm{C})$. These collective data support the notion that normal endochondral bone formation incorporates replicative senescence during the late chondrogenic phase and that PRC1 complexes play a pivotal role in preventing premature chondrogenic hypertrophy.

\section{Discussion}

In the current study, we establish a hitherto unknown involvement of BMI1 in chondrogenesis. We define a crucial role for PRC1 during differentiation-associated TA and provide a detailed analysis of the cellular and molecular consequences of PRC1 functional deficiency in TA chondrogenic progenitors. In the absence of BMI1, cells fail to coordinate de novo DNA synthesis and active DNA transcription during TA. We establish that failure to remove chromatin-bound TOP2 $\alpha$ complexes correlates with reduced DNA replication. Simultaneously, GMNN accumulation correlates with hampered chondrogenic transcriptional programming, as evidenced by coinciding, apparently non-H3K27me3-directed, transcriptional deregulation, hyperphosphorylation and enhanced degradation of RPOL2A. Our collective data suggests that the absence of PRC1-E3 ligase activity toward TOP $2 \alpha$ results in massive accumulation of replication-associated DSB, which evokes a DDR-induced intraS-phase cell cycle arrest. Ultimately, a replication damage-associated SLR blocks functional chondrogenic progenitor expansion and differentiation. We present evidence that programmed replicative senescence is an essential part of normal endochondral bone formation and that DDR-induced SLR during chondrogenesis enhances hypertrophy during the formation of long bones of a PRC1-mutant mouse and is likely to contribute to skeletal malformations. To the best of our knowledge, the findings described herein for the first time provide a molecular basis for PRC1-mediated coordination of multiple DNA-templated processes during TA in chondrogenesis and position PRC1 as a ubiquitin E3 ligase for TOP2 $\alpha$ in a relevant developmental context.

Our current and previous collective data suggests that $\mathrm{H} 3 \mathrm{~K} 27 \mathrm{me} 3$ is not a primary determinant of PRC1-mediated transcriptional repression. We have recently shown that transcriptional activity persists during differentiation or physiological stress, despite increased genic H3K27me3-enrichment [33,55-57]. Conversely, PRC1 was suggested to be required for gene expression in specific settings [58-62], illustrating the complexity of the functional interaction between PRC1 and H3K27me3 in the context of transcriptional regulation. H3K27me3-decoration may provide local epigenetic marking that directs lineage-dependent coordination of DNA transcription, replication. This notion is also in line with recent observations that H3K27me3-marking correlates primarily with overall transcriptionally repressed status prior to physiologically induced (i.e., differentiation, stress) transcriptomic changes and that H3K27me3-marking hampers reprogramming within and between lineages [33,56,57,63-65]. Increased global histone H3K27 and H3K9 trimethylation in BMI1-deficient ATDC5 cells may be an indicator of cellular/chromatin stress and concurrent protective responses rather than transcriptional deregulation per se. We have recently shown that inhibition of the H3K27-demethylase JMJD3 under low oxygen conditions is responsible for epigenome-wide enhanced H3K27me3 [33,57]. As chondrogenesis prominently features proliferation and differentiation under hypoxic conditions and JMJD3 was reported to promote proliferation and hypertrophy during chondrogenesis [66], a regulatory involvement of histone trimethylation by JMJD3 would appear plausible. Increased methylation at H3K9, H3K27 and H4K20 have been correlated with cell-cycle exit and cell death [67,68]. In keeping 
with this idea, we recently reported abnormal global trimethylation at H3K4, K9 and K27 in the context of defective TA in chondrogenic differentiation [19]. We currently have no definitive explanation for the decline of H3-associated trimethyl-marks at later stages in development. Although mRNA levels of the corresponding epigenetic effector PRC2 complex members EZH2, EED, SUZ12 (H3K27me3) and SUZ39H2, SETD1 proteins (H3K9me3) decreased toward later stages of differentiation (cf. Figure S1A), it is unclear whether and how these Lysine methyl transferases (KMT) and/or their functional demethylating counterparts (KDM) are involved in late chondrogenic epigenomic changes. Whereas senescence has been associated with enhanced nuclear H3K9me3 (also see below) [49], whether and how increased global H3K27me3 is also connected to cellular senescence is less clear at this time.

BMI1/RING1 were identified as an important E3-ligase complex targeting TOP2 $\alpha$ for ubiquitin-mediated degradation in a siRNA-based screen for increased toxicity of TOP2-directed drugs: in the absence of functional PRC1, TOP2 $\alpha$ cleavable complexes accumulate on chromatin, which has obvious relevance for cancer therapy, as it increases sensitivity for Topo-directed drugs [39]. We here establish that, besides RING1 and BMI1, RNF2 and PHC2 are also crucial partners in the functional interaction between PRC1 and TOP $2 \alpha$. We here define for the first time a functional significance for this biochemical relationship in a relevant development context. Our analyses point to transcriptional deregulation during TA in the absence of functional PRC1, rather than a simple failure to repress specific PRC1 targets in defined differentiation routes. We propose a model in which PRC1, via its Ubiquitin E3-ligase activity, functionally connects DNA replication, transcription and repair via several regulatory nodes associated with chromatin. This idea is good agreement with the observations that PRC2 complexes are localized to replication forks and control progression and symmetry of DNA replication forks ([38,69]. Among potential candidate partners for such a regulatory liaison is GMNN. GMNN is involved in lineage commitment and differentiation through mechanisms involving Polycomb Group proteins and prevents re-replication at the end of S-phase; in addition, GMNN and PRC1 co-regulate gene transcription $[45,47,48]$. Loss of PRC1 E3-ligase function was shown to stabilize GMNN, which interferes with haematopoietic stem cell self-renewal [46]. Dynamic segregation of mRNA and DNA synthesis is known to occur throughout S-phase, as proximity of transcription and replication forks increases the risk of fork collisions and DNA damage. We observed an increase in $\mathrm{yH} 2 \mathrm{AX}$ phosphorylation that coincided in space and time with sites of active DNA replication during transit chondrogenic proliferative amplification. Although we cannot formally rule out an involvement of additional PIKK-family kinases in the phosphorylation of histone variant H2A.X and the resolution thereof at later differentiation stages, based on the evidence provided herein, we interpret the enhanced DSB as the outcome of increased replication stress, in coherence with a recent report on the effect of loss of PRC2 function [38]. It is conceivable that in part the DNA damage results from failure to remove covalently bound TOP2A cleavage complexes. Spatio-temporal coordination of replication and transcription is re-defined during differentiation [70-72]. Of note, this occurs in midS-phase, a period during which we and others have observed dynamic regulation of PRC1-chromatin association involving PRC1 phosphorylation [73]. As PRC complexes were shown to remain associated with chromatin during DNA replication $[36,69,74]$, this ideally positions PRC1 to locally tune transcription to replication activity. Of relevance, PRC1-proteins were shown to occupy promoters of actively transcribed genes and are required for POLR2A complex disassembly [41,75]. We recently showed transcriptional activation of the immediate early gene ATF3 in response to mitogenic signaling, involves release of chromatin-bound PRC1-complex members without the need for local change in promoter H3K27me3-marking [55]. PRC1-mediated transcriptional repression, instead, appears to be dependent on ubiquitylation of H2AK119, which is also involved in DNA repair [76-78]. It is conceivable that PRC1-dependent E3 ligase activity toward specific targets, e.g., H2AK119, GMNN and/or TOP2A and PRC1 complex composition are locally controlled by specific post-translational modification [79-81]. It is thus tempting to speculate that the PRC1-GMNN partnership represents a molecular choice mechanism between DNA replication (GMNN absent) and RNA synthesis (GMNN present) which, via H3K27me3-directed positioning of PRC1 complexes, plays a vital role in 
lineage-dependent spatio-temporal control of transcription and replication during development. In this light, a comparative study on effects of PRC2-depletion on replication and transcription timing in embryonic stem cells and neuronal progenitors revealed premature expression of lineage-specific genes [82]. The chondrogenic model, which incorporates both PRC1-mediated proliferative and transcriptional reprogramming during mesenchymal lineage-commitment, encompasses the required dynamics to study replication and transcription timing in the context of PRC1 function.

Our collective findings reported in this study support a thus far unrecognized cell-autonomous role for BMI1/PRC1 in proliferative and transcriptional control during endochondral bone formation. The resulting cell cycle arrest and premature senescence-like hypertrophy is expected to contribute to abnormal formation, development and growth of the skeletal elements in PRC1-mutant animals, in addition to abnormal A-P positioning due to defective establishment and/or maintenance of Hox-gene expression boundaries $[4,6]$. We here report that chondrogenic hypertrophy shares multiple cellular and molecular characteristics with replication-stress induced senescence. Chondrocytes harbor a remarkable ability to hyper-proliferate under conditions unfavorable for cell division (e.g., cartilage is avascular and hypoxic) [83]. Interestingly, a recent report showed that PRC-mediated gene regulation of the checkpoint involving $\mathrm{CDKN} 2 \mathrm{~A} / \mathrm{P} 16^{\mathrm{INK} 4 \mathrm{~A}}$ is dependent on the physiological oxygen levels [38]. Given that chondrogenic cultures rapidly become confluent and multi-layered and thus likely hypoxic, this may explain the apparent insensitivity of transcriptional activity at the $C d k n 2 a$ locus to BMI1-depletion. In addition, chondrogenesis greatly relies on enhanced endoplasmic reticulum-stress signaling (ERSS) and unfolded protein response (UPR) [84,85]. Both ERSS and UPR are known inducers of oncogene-induced senescence (OIS) [86]. Hyperproliferation-associated replication damage and senescence are important features of OIS and suggest functional analogy with chondrogenic hyperproliferation/hypertrophy. A biological analogy between chondrocyte hypertrophy and programmed cellular senescence is also consistent with the role for RUNX proteins both in endochondral ossification and in OIS [87,88]. Of note, BMI1 rescues oncogenic H-RASV12-associated OIS and thereby cooperates with RAS in oncogenesis [89]. Hence, enhanced BMI1 expression during chondrogenic TA shares important molecular characteristics with cellular responses to oncogenic activation and emphasizes a pivotal role for PRC1 in facilitating DNA replication under conditions of enhanced chromatin remodeling.

BMI1 is regarded as a stem cell marker, as ablation of PRC1 function is associated with depletion of stem cell compartments due to defective self-renewal [14-16]. A mechanistic, cell biological explanation for compromised stem cell self-renewal capacity in the context of PRC1-deficiency, however, remained unclear. PRC and stem cell transcription factors (SCTF) like Nanog, are known to co-occupy key developmental regulators genes in embryonic stem cells (ESCs) and SCTFs are PRC-targets themselves [90-93]. Of relevance, instead of a typical TP53-dependent DDR and apoptosis in response to DSB, ESCs accumulate TP53 at the promoter of the gene encoding the stem cell transcription factor Nanog which leads to down-regulation of Nanog expression [94]. Integrity of the stem cell compartment is thus maintained by elimination of damaged ESCs via induction of differentiation. In light of our findings, it is conceivable that replication-mediated DNA damage and induced abnormal differentiation may contribute to loss of self-renewal in PRC1-deficient totipotent stem cells.

The collective findings presented in this study show that defective coordination of DNA and RNA synthesis during chondrogenic TA in the absence of functional PRC1, is a major source of replication stress, encompassing DNA damage, DDR and SLR. Our observations suggest a central regulatory role for PRC1 at the cross-roads of DNA transcription, replication and repair in transit amplifying progenitor cells, in line with an important role for PRC1 in replication-associated chromatin damage-avoidance. These findings have important implications for the mechanistic understanding of PRC1 proteins in stem cell biology, in embryogenesis and regenerative applications and in oncogenesis and are expected provide new leads for further study. 


\section{Methods}

\subsection{Cell Culture, Differentiation Assays}

Differentiating ATDC5 cultures become multi-layered and develop distinctive three-dimensional nodules that produce cartilage matrix proteins [21]. ATDC5 differentiation is monitored by sequential chondrogenic marker gene expression (e.g., Sox9, Runx2, Col2A1, PZ; Acan and Col10A1, HZ; Figure 1A) [20]. Culture conditions chondrogenic cells (ATDC5, HAC, kper): $37{ }^{\circ} \mathrm{C}, 5 \% \mathrm{CO}_{2}, 100 \%$ humidity; DMEM/F-12, 5\% FCS (supplements: Penicillin/Streptomycin, L-Glutamin). Human U2-OS osteosarcoma or SW1353 cells chondrosarcoma were maintained in DMEM, or DMEM/F12, respectively, supplemented with 10\% FCS. HAC from a single donor were obtained from the unaffected regions of osteoarthritic (OA) cartilage from total knee arthroplasty (Medical Ethical Committee (MEC) approval 08-4-028). Rabbit-derived chondrogenic cells (COP, kper) were obtained as surplus surgical material in non-related procedures (Animal Ethical Committee (DEC) approval 2005-159). For differentiation experiments ( 6400 cells $/ \mathrm{cm}^{2}$, overnight attached) ITS differentiation medium $(10 \mu \mathrm{g} / \mathrm{mL}$ Insulin, $10 \mu \mathrm{g} / \mathrm{mL}$ Transferrin, $3 \times 10^{-8} \mathrm{M}$ Sodium Selenite) was used for all cells. De novo DNA replication: cells were incubated with $\mathrm{BrdU}(100 \mathrm{nM} / \mathrm{mL})$ for the indicates timespan. Etoposide was added for $30 \mathrm{~min}$; cells were then washed and grown for an additional 9 days.

\subsection{Retroviral Vectors, Infections}

Retroviral systems and Phoenix helper-free retrovirus producer cell lines were used as published before $[95,96]$. Ecotropic retroviral supernatants were produced by transfection of producer cells with calcium-phosphate precipitation; $24-48 \mathrm{~h}$ post-transfection, the supernatant was harvested, filtered and used for transduction of ATDC5, HAC or U2-OS cells in presence of $4 \mu \mathrm{g} / \mathrm{mL}$ polybrene. For transduction, cells were incubated with viral suspensions for $12 \mathrm{~h}$ and allowed to recover for $24 \mathrm{~h}$ on fresh medium before selection pressure was applied. Transduced cells were selected with puromycin $(8 \mu \mathrm{g} / \mathrm{mL})$ for $72 \mathrm{~h}$, before experiments were initiated; at the onset of experiments the puromycin concentration was lowered to $2 \mu \mathrm{g} / \mathrm{mL}$ for the duration of the experiment. shRNAi vectors were based on the pRetrosuper system (courtesy R. Agami, Amsterdam, The Netherlands) [97]. Efficacy of shRNAi vectors was verified in U2-OS cells expressing tagged target proteins (Bmi1-2PY, HA-Rnf2, $H A-P h c 2)$. The human + murine $s h B m i 1[h+m]$ vector targeted human BMI1 and efficiently reduced recombinant and cellular murine BMI1 levels. shGFP (courtesy A. Goodarzi, Calgary, Canada) was used as reference shRNAi (shcon) throughout these studies [98]. Target sequences used:

\section{shBmi1 $[m+h]$ (ENSMUSG00000028796): 5'-GTTCACAAGACCAGACCAC-3', shRnf2[m] (ENSMUSG00000028796): 5'-GTATCTGGCTGTGAGGTTA-3', shPhc2[m] (ENSMUSG00000028796): 5'-GTTCAAGCGTTCCAAGCGC-3'.}

\subsection{Proliferation Assays}

ATDC5 cells were plated in 12-multiwell plates (Greiner Bio-One B.V, Alphen aan de Rijn, The Netherlands). At each time point cells were washed twice with phosphate-buffered saline and fixed for 10 min with $3.7 \%$ formaldehyde at room temperature. Next, cells were rinsed 5 times with demineralized water. Cells were stained with $0.1 \%$ Chrystal violet for $30 \mathrm{~min}$ or overnight and washed 5 times with demineralized water. Chrystal violet was extracted with $10 \%$ acetic acid and absorbance was measured spectrophotometrically at 590 nm (Benchmark, Biorad, München, Germany).

\subsection{Immunoblot Analysis}

Cells were lysed in RIPA buffer containing $5 \mathrm{mM}$ Benzamidine, $5 \mu \mathrm{g} / \mathrm{mL}$ Antipain, $5 \mu \mathrm{g} / \mathrm{mL}$ Leupeptin, $5 \mu \mathrm{g} / \mathrm{mL}$ Aprotinin, $1 \mathrm{mM}$ Sodium Vanadate, $10 \mathrm{mM}$ Sodium Fluoride, $10 \mathrm{mM}$ Pyrophosphate, $10 \mathrm{mM} \beta$-Glycerophosphate, $0.5 \mathrm{mM}$ DTT and $1 \mathrm{mM}$ PMSF. Lysates were subjected to 3 freeze-thaw cycles in liquid nitrogen and to 3 cycles of sonication. After centrifugation for $10 \mathrm{~min}$ 
at $13.2 \mathrm{k} \mathrm{rpm}$, protein concentration was determined using a BCA protein assay kit (Pierce). Equal amounts of protein were boiled in Laemmli buffer and loaded on 9-15\% Polyacrylamide gels. Proteins were transferred to Polyinylidene Fluoride (PVDF) membranes. After blocking with $5 \%$ non-fat dry milk in PBS containing $0.1 \%$ Tween-20, membranes were incubated $\mathrm{o} / \mathrm{n}$ at $4{ }^{\circ} \mathrm{C}$ with primary antibodies. After extensive washing, membranes were incubated with corresponding horseradish Peroxidase conjugated secondary antibodies for $1 \mathrm{~h}$ at room temperature. Signals were detected using enhanced chemoluminescence. Quantitative analysis was carried out using Chemi Luminescent Image capture software (Chemidoc XRS, Biorad, München, Germany). Cell fractionation assays were carried out as described before: quantitative comparison between different fractions was enabled by loading volume equivalents [55].

\subsection{Immunofluorescence}

Briefly, cells were washed and fixed for $10-15 \mathrm{~min}$ in $100 \%$ Methanol at $-20{ }^{\circ} \mathrm{C}$ and stored at $4{ }^{\circ} \mathrm{C}$ in $70 \%$ Ethanol or used directly for immunocytochemistry. Cells were permeabilized for 5-10 min in 0.2 \& Triton- $X$ in PBS. To prevent epitope loss in combination with acid treatment for BrdU detection, primary antisera were incubated for $1.5 \mathrm{~h}$ at $37^{\circ} \mathrm{C}, 4-5 \times$ washed in $0.02 \%$ triton-X/PBS and fixed in $2 \%$ Formaldehyde/PBS for $10 \mathrm{~min}$ at room temperature. Cells were washed with PBS and incubated for $20 \mathrm{~min}$ in $2.0 \mathrm{~N} \mathrm{HCl}$ at $37^{\circ} \mathrm{C}$, followed by two rinses of $0.1 \mathrm{M}$ Sodium Tetraborate solution, $\mathrm{pH} 8.5$ for in total $2 \mathrm{~min}$. Cells were than incubated with the primary antisera against BrdU, washed at indicated before and incubated with secondary fluorescently labeled antibodies. All antisera were diluted and incubated in $0.02 \%$ Triton- $X$ in PBS. Nuclei were counterstained with $4^{\prime}$-6-Diamidino-2-Phenylindole (DAPI) and washed in $0.02 \%$ Triton-X/PBS. The last wash step was in PBS, upon which cells were dehydrated: $1 \mathrm{~min}$ in $70 \%$ Ethanol, $2 \times 1 \mathrm{~min}$ in 100\% Ethanol and air-dried and mounted in Vectashield (Vector Laboratories, Inc. Burlingame, CA, USA). Parallel images of shcon and shBmil cells were acquired using identical exposure times at identical magnification throughout this study and were analyzed using a NIKON TE200 Eclipse fluorescence microscope and photographed using a NIKON DXM1200 digital camera in combination with NIS Elements 3.0 Imaging software (Nikon Instruments Europe B.V., Amsterdam, The Netherlands). For quantification of IF images, at least 100 randomly selected cells (based on DAPI or phase contrast image) were counted per genotype (i.e., shcon, shBmi1); IF-positivity, as indicated in (supplemental) figures or figure legends, was expressed as a percentage of total number of counted cells.

\subsection{Antibodies}

Anti- $\beta$-ACTIN (C4, 691001, MP Biomedicals, Eschwege, Germany), anti-GAPDH, anti-H3K27me3 (\#07-449), anti-H3K9me3 (\#07-442), anti-H3S10Ph (\#06-570), anti- $\gamma$ H2A.X (JBW301), anti-PCNA (PC10) (EMD Millipore, Amsterdam, The Netherlands, ,anti-yH2A.X (Ser139; \#2577) (Cell signaling), anti-BrdU (BD Biosciences, Leiden, The Netherlands), anti-EZH2 (courtesy D. Pasini; Copenhagen, Denmark), anti BMI1(F6) (courtesy M.vLohuizen, Amsterdam, The Netherlands), anti-PHC2 and anti-RNF2 (courtesy of H.Koseki, Chiba, Japan [99]), anti-RING1 (courtesy A.Otten, Amsterdam, The Netherlands [100]), anti-GMNN (sc-13015), anti-RAD51 (sc-8349; Santa Cruz, CA, USA), anti-pKAP1 (S824) A300-767A (Bethyl Laboratories, Montgomery, TX, USA), anti-COL2A1 II-II6B3 (Hybridoma bank, Iowa city, IA, USA), anti-COL10A1 (courtesy G.P.Lunstrum, Portland, OR, USA), anti-BMI1 (ab38432), anti-POLR2A (ab817), anti-pPOLR2A II (ab24759), anti-RPA70 (ab12320), anti-TOP2A (ab73724; Abcam, Cambridge, UK).

\subsection{Single Cell Gel Electrophoresis Assay (Neutral Comet Assay)}

Suspended cells $\left(0.5 \%\right.$ of low melting point agarose/PBS, $\left.37^{\circ} \mathrm{C}\right)$ were dispersed on microscope coated slides (1.5\% agarose). Slides were lysed (overnight, $4{ }^{\circ} \mathrm{C} ; 2.5 \mathrm{M} \mathrm{NaCl}, 100 \mathrm{mM}$ EDTA, $10 \mathrm{mM}$ Tris, $250 \mathrm{mM} \mathrm{NaOH}, 1 \%$ Sodium Lauryl Sarcosinate, 10\% DMSO and 1\% Triton X-100, pH 10), subjected to electrophoresis $\left(20 \mathrm{~min}, 25 \mathrm{~V}, 300 \mathrm{~mA}, 4^{\circ} \mathrm{C}\right)$, fixed $(100 \%$ ethanol) and stained $(20 \mu \mathrm{g} / \mathrm{mL}$ Ethidium 
Bromide). A minimum of 100 nuclei was scored per sample, per time point (Comet assay III software; Perceptive Instruments, Haverhill, UK). Mean Comet tail moments were used to assess DSB in triplicate assays; statistical analyses: two-sided, non-paired t-testing.

\subsection{RNA Isolation, cDNA Synthesis, Quantitative PCR Analysis}

For quantitative PCR (qPCR) analysis, total RNA from three independent parallel experiments was isolated using Tri-Reagent (Sigma) according to the manufacturers' protocol. Quantity and quality of the RNA were determined by $260 / 280 \mathrm{~nm}$ and $260 / 230 \mathrm{~nm}$ absorbance measurements, respectively, using the Nanodrop (Witec AG, Luzern, Switzerland). Total RNA $(1 \mu \mathrm{g})$ for each sample/replicate was converted into first strand cDNA using the iScript ${ }^{\mathrm{TM}}$ CDNA synthesis kit (Bio-Rad, Herculus, CA, USA) according to the manufacturers' instructions. Gene expression was determined by real-time qPCR using the MyiQ ${ }^{\mathrm{TM}}$ Thermal Cycler (Bio-Rad) in combination with the IQ5 v2 software (Bio-Rad). qPCR was performed on $25 \mathrm{ng}$ of $\mathrm{CDNA}$ using the $\mathrm{qPCR}_{\mathrm{iQ}}{ }^{\mathrm{TM}}$ Custom SYBR ${ }^{\circledR}$ Green Supermix with fluorescein (Bio-Rad) and $300 \mathrm{nM}$ primer in 96 well plates (Bio-Rad). For each primer pair a standard curve was generated with a serial dilution of a cDNA pool. qPCR data was analyzed according to the relative standard curve method. All values were normalized to Cyclophillin A. The control conditions were used as a reference. Primer sets for the selected genes were developed with Primer Express version 2.0 (Applied Biosystems, Foster City, CA, USA) using default settings (see below).

\subsection{Affymetrix Expression Arrays, Pathway Analysis}

For gene expression arrays, three independent replicate RNA samples were taken at each time point during differentiation $(0,2,4,8 \mathrm{~h}, 1,6,10$ and 15 days) from shcon and shBmil cultures. Total RNA was isolated using the RNeasy kit (Qiagen, Venlo, The Netherlands) according to the manufacturers' protocol. The isolated RNA samples were processed by ServiceXS BV (Leiden, The Netherlands) according to Affymetrix (Santa Clara, CA, USA) protocols. In brief, RNA concentration was measured by absorbency at $260 \mathrm{~nm}$ using the Nanodrop (Nanodrop Technologies, Wilmington, DE, USA) and RNA quality and integrity was verified by using the RNA 6000 Nano assay on the Agilent 2100 Bioanalyzer (Agilent Technologies, Palo Alto, CA, USA). For each sample $2 \mu \mathrm{g}$ high quality total RNA was labeled using the Affymetrix Eukaryotic One-Cycle Target Labeling and Control reagents to generate Biotin-labeled cRNA. The quality of the cRNA was verified using the Agilent 2100 bioanalyzer and the concentration was measured using the Nanodrop (Nanodrop Technologies, Wilmington, DE, USA). Labeled cRNA was used for hybridization to 48 custom Affymetrix NuGO Mouse GeneChip arrays (NuGO_Mm1a520177). After an automated process of washing and staining, absolute values of expression were calculated from the scanned array using the Affymetrix GCOS software. Data preprocessing and analysis was conducted based on scripts from ArrayAnalysis.org using R2.7.1 [101] and Bioconductor libraries (http://www.R-project.org) [102]. Data were 2log transformed and normalized (gcRMA) [103]. Probe annotations were updated using the Ensembl based Brainarray annotation file [104]. Statistics computation for each reporter on the arrays included: the average (2logged) expression of each group, the logratio (2log fold change) between the two groups and the $t$ - and $p$-value of a Student $t$-test, all for each time point. Subsets of reporters fulfilling specific criteria were selected for various analyses, where generally cut-offs on p-value, logratio and minimum expression $(p<0.05$, absolute FC (fold change) $\geq 2$, expression $>2 \log (100)$ in either group, at any time point) were imposed and controls removed from the data set. For pathway $Z$ score analysis, expression at any given time point was compared between the respective genotype and referenced to $t=0$; overall shBmil $/ t=0$ expression signal was normalized against shcon $/ t=0$. Unless otherwise specified (Figure legends), cut-off limits had to be met at either $t=1$ or 6 days pid. GenMAPP was used for biological process annotation [105]. Overrepresentation of biological processes was determined using PathVisio (http://www.pathvisio.org) using pathways available through WikiPathways (www.wikipathways.org) [106]. 
4.10. H3k27me3 Chip-Seq, Data Processing: Alignment, Normalization, Background Correction, Identification of Enriched Regions

Cells were disrupted by sonication, yielding genomic DNA fragments ranging from 200-1000 bp, with a bulk size of 200-500 bp. For each immunoprecipitation 10-20 million cells were used. $1 \%$ of the cell suspension was kept aside as input DNA to use as a reference. Chromatin immunoprecipitation (ChIP) was performed and analyzed as described before with minor adjustments [93]. ChIP-grade H3K27me3 antiserum: 07-449 (Upstate). Immunoprecipitated DNA was checked for enrichment using real-time PCR and quantified by fluorescence detection using Quant-iT ${ }^{\text {TM }}$ Picogreen ${ }^{\circledR}$ dsDNA Reagent (Molecular Probers/Invitrogen, Eugene, OR, USA) before deep sequencing was applied. Input and ChIP samples were further processed and sequenced using the Illumina next generation sequencing platform as described [107].

Image processing and base calling was performed using Illumina software tools provided by the manufacturer. Subsequent genome alignment was performed using Bowtie with Mouse Genome Build 9 (MM9) used as a reference genome, keeping uniquely aligned reads only for further analysis. To remove PCR artifacts, all data were collapsed prior to peak calling. H3K27me3 data sets were normalized based on genes with stable H3K27me3-enrichment $(>0)$ in shcon and shBmi1 samples at both 0 and $3 \mathrm{~h}$ pid; the cumulative area under the curve for all peaks within these regions was scaled relative to the smallest value among the samples. H3K27me3-marking at the HoxA cluster, which harbors both PRC1-target (i.a. HoxA9-13) and non-target loci (i.a. HoxA1-4) [19] was used to exemplify stable H3K27me3-enrichment at $\mathrm{t}=0$ and $\mathrm{t}=3$ days pid (Figure S8A,B). The H3K27me3 enrichment level, i.e., peak height, associated with stably and actively transcribed genes was used as a cut-off for all samples. The reasoning is that such genes should have no or very low levels of H3K27me3 enrichment. Stably and actively transcribed genes were defined as having a minimum expression larger than 99th percentile of the minimum expression values of all genes across (i) shcon and shBmi1 and across (ii) all time-points for which gene expression data was available. The cut-off corresponds to an estimated H3K27me3 enrichment FDR of 1\%, i.e., the proportion of genes classified as H3K27me3-marked while the intensity of these markings is within background level is expected to be equal or less than $1 \%$. Signal intensities below this cut-off were not considered biologically relevant. To identify enriched regions in the ChIP samples, the peak caller Findpeaks (version 4.0) was used with settings adjusted to detect blanketing enrichment (a well-known problem for H3K27me3 enrichment finding), next to sharply defined peaks.

\subsection{H3K27me3-Enrichment Data Summarization, Integration Gene Expression Data}

To quantify enrichment, each gene was divided into three regions: the promoter region $(-3000 /-100$ base pairs (bp) in relation to the TSS), the TSS region $(-100 / 1000 \mathrm{bp})$, the gene body region (+1000 bp to the end of the last exon). The total area under the curve for each region was calculated and $\log 10$ transformed. Based on these quantifications, 2-fold changes in either direction were considered as substantial changes in H3K27me3-enrichment, while fold changes smaller than 0.5 were considered a sign of stable H3K27me3-enrichment. Genes with enrichment changes between 0.5 and 2 were not considered for differential occupation analyses. Only genes for which both expression data (see above) as well as H3K27me3-enrichment data (enrichment $\geq 0$ ) was available were considered for further analysis (16261 genes in total). For the identification of enriched genes, we defined a gene as the region between its $5^{\prime}$ (most upstream TSS) and $3^{\prime}$ (last exon) end plus $5 \mathrm{~kb}$ regulatory regions up and downstream respectively. A gene was called marked when there was a peak present within this region as determined by the enrichment finding procedure outlined above.

\subsection{Cross-Link Immunoprecipitation (X-IP), Deep-Sequencing, Chromatin-Association Studies}

Briefly, ATDC5 cells were fixed in 1\% formaldehyde. Cross-linking was allowed to proceed for $10 \mathrm{~min}$ at room temperature and stopped by addition of glycine at a final concentration of $0.125 \mathrm{M}$, followed by an additional incubation for $5 \mathrm{~min}$. Fixed cells were washed twice with PBS and harvested 
in SDS Buffer (50 mM Tris at pH 8.1, 0.5\% SDS, $100 \mathrm{mM} \mathrm{NaCl}, 5 \mathrm{mM}$ EDTA), supplemented with protease inhibitors (Aprotinin, Antipain and Leupeptin all at $5 \mu \mathrm{g} / \mathrm{mL}$ and $1 \mathrm{mM}$ PMSF). Cells were pelleted by centrifugation and suspended in IP Buffer (100 mM Tris at $\mathrm{pH} 8.6,100 \mathrm{mM} \mathrm{NaCl}, 0.3 \%$ SDS, $1.7 \%$ Triton X-100 and $5 \mathrm{mM}$ EDTA), containing protease inhibitors. Cells were disrupted by sonication, yielding genomic DNA fragments with a bulk size of 200-500 bp. For each immunoprecipitation, $1 \mathrm{~mL}$ of lysate was precleared by addition of $35 \mu \mathrm{L}$ of blocked protein A beads (50\% slurry protein A-Sepharose (Amersham/Sigma-Aldrich, Zwijndrecht, The Netherlands); $0.5 \mathrm{mg} / \mathrm{mL}$ fatty acid-free BSA, Sigma; and $0.2 \mathrm{mg} / \mathrm{mL}$ herring sperm DNA in TE), followed by clarification by centrifugation. $10 \mu \mathrm{L}$ aliquots of pre-cleared suspension were reserved as input DNA and kept at $4{ }^{\circ} \mathrm{C}$. Samples were immunoprecipitated overnight at $4{ }^{\circ} \mathrm{C}$ with antibodies for H3K27me3 (07-449; Upstate). Immune complexes were recovered by adding $40 \mu \mathrm{L}$ of blocked protein $\mathrm{A}$ beads and incubated for $4 \mathrm{~h}$ at $4{ }^{\circ} \mathrm{C}$. Beads were washed three times in $1 \mathrm{~mL}$ of mixed micelle buffer $(20 \mathrm{mM}$ Tris at $\mathrm{pH} 8.1,150 \mathrm{mM} \mathrm{NaCl}$, $5 \mathrm{mM}$ EDTA, $5 \% \mathrm{w} / \mathrm{v}$ sucrose, $1 \%$ Triton X-100 and 0.2\% SDS), twice in $1 \mathrm{~mL}$ of Buffer 500 (50 mM HEPES at pH 7.5, 0.1\% $w / v$ Deoxycholic Acid, $1 \%$ Triton X-100 and $1 \mathrm{mM}$ EDTA), twice in $1 \mathrm{~mL}$ of LiCl Detergent wash buffer (10 mM Tris at pH 8.0, 0.5\% Deoxycholic Acid, 0.5\% NP-40, $250 \mathrm{mM} \mathrm{LiCl}$ and 1 $\mathrm{mM}$ EDTA) and once in $1 \mathrm{~mL}$ of TE. Immuno-complexes were eluted from beads in $250 \mu \mathrm{L}$ elution buffer ( $1 \%$ SDS; and $0.1 \mathrm{M} \mathrm{NaHCO}$ ) for $2 \mathrm{~h}$ at $65{ }^{\circ} \mathrm{C}$ with continuous shaking at $1000 \mathrm{rpm}$ and after centrifugation supernatants were collected. $250 \mu \mathrm{L}$ elution buffer was added to input DNA samples and these were processed in parallel with eluted samples. Crosslinks were reversed overnight at $65^{\circ} \mathrm{C}$ followed by a $2 \mathrm{~h}$ digestion with RNAse A at $37^{\circ} \mathrm{C}$ and $2 \mathrm{hrs}$ proteinase $\mathrm{K}(0.2 \mu \mathrm{g} / \mu \mathrm{L})$ at $55^{\circ} \mathrm{C}$. DNA fragments were recovered using QIAquick PCR purification columns, according to manufacturers' instructions. Samples were eluted in $75 \mu \mathrm{L}$ EB buffer and then further $1 / 5$ diluted in TE buffer.

To assess relative proximity of replication and transcription machineries, cross-linked chromatin (10 $\mathrm{min}, 1 \%$ formaldehyde, room temp) was sheared to a fragment size range of $\pm 3000-5000 \mathrm{bp}$ and used for reciprocal IPs. Equal chromatin-input in IPs was assessed by DNA concentration measurement. For TOP2A/chromatin-association, no fixation was applied; a mild lysis was used $(250 \mathrm{mM} \mathrm{NaCl}, 0.1 \%$ Nonidet P-40, 5 mM EDTA, 50 mM HEPES, pH 7.0; supplemented with inhibitor cocktail) to separate total soluble from chromatin-bound fractions as described before [55]. Soluble fractions were collected after centrifugation; chromatin pellets were washed; all samples were sonicated before analysis (see: Western analysis).

\subsection{Senescence-Associated Beta-Galactosidase Staining}

Murine or human skeletal elements were fixed ( $0.2 \%$ Glutaraldehyde, $24 \mathrm{~h})$. Upon staining, tissues were cleared using a series of clearing solutions containing $1 \% \mathrm{KOH}$ in $0 \%, 20 \%, 50 \%$ and finally $100 \%$ Glycerol. Human (HAC, SW1353), rabbit (CPO, kper) and mouse (ATDC5) cell lines were cultured and differentiated as indicated above. Fixation and SA- $\beta$ GAL staining was done as described before [54].

\subsection{Mice, Tissue Histology}

Mouse and human bone tissues were decalcified (0.3 M EDTA, pH 7.4; 1 week and 0.5 EDTA, pH 7.8, 4 weeks). PRC1-epitopes were retrieved by boiling (20 min, 0.01 M Citrate buffer, $\mathrm{pH}$ 6.0; passive cooling). Collagen epitope retrieval: digestion with $0.4 \%$ Hyaluronidase. Decalcified 7 micron slices of RING1 +/+, + - and - / - mice were stained for ECM collagens with Sirius-red. HZ-widths were scored blinded by two independent investigators $(n=4, K O ; n=8, H E ; n=2$, WT); statistical analysis: standard t-test. Bone elements were fixed ( $24 \mathrm{~h}, 4 \%$ Formaldehyde), precleared (1-3 days, $1 \% \mathrm{KOH}$ ) and stained (overnight, Alcian Blue $0.14 \% w / v$, Alizarin Red $0.12 \% w / v$ in $20 \%$ Glacial Acetic Acid $/ 80 \%$ Ethanol) and washed with 96\% Ethanol. Tissues were cleared for more than 6 weeks (see: $S A-b G A L$ staining). Use of human surgical surplus material was in accordance to Medical Ethical Review Committee guide lines (METC 08-4-021). All animal work was performed according to local ethical guidelines for animal experimentation. 
Supplementary Materials: The following are available online at www.mdpi.com/2075-4655/1/3/22/s1.

Acknowledgments: The authors thank R. Berezney (Buffalo, NY), C. Logie (Nijmegen, The Netherlands) and R. Shiri-Sverdlov (Maastricht, The Netherlands) for valuable feedback. We thank B. Schutte, M. Henfling, R. Godschalk, D. Meesters and W. Wetzels (Maastricht, The Netherlands) for expert technical assistance and M. Caron and L. van Rhijn (Orthopedics dept., Maastricht, the Netherlands) for providing primary human material. We apologize to any colleague whose original work was not cited; these studies are properly referenced in reviews cited throughout this manuscript. The authors received financial support from the European Molecular Biology Organization (Germany; www.embl.de) ASTF5-2009 (F.S.) and the René Vogels foundation (F.S.); grant BFU2010-18146 (MINECO, MV) and Oncocycle program S2010/BMD2470 (Comunidad de Madrid, MV); the Dutch Science Organization (ZonMW-NWO; www.NWO.nl) VIDI grant 864.12.007 (H.M.); VIDI grant 016.046.362 (J.W.V.); Netherlands Reuma foundation (The Netherlands; www.ruemafonds.nl) grant LLP14 (J.W.V., L. van Rhijn, Maastricht, The Netherlands) and a transnational University of Limburg grant (J.W.V., B.W.G.).

Author Contributions: F.S., L.M.T.E., M.E.A., B.G.W. and J.W.V. conceived and coordinated the study; F.S., P.P., J.S., V.E.H.D., F.K., T.J.W., D.A.M.S., R.K., Y.T., M.V. and J.W.V. contributed to experimentation and analyses; H.M. and H.G.S. generated deep-sequencing data; L.M.T.E. and M.E.A. were responsible for all bioinformatics analyses. F.S., L.M.T.E., M.E.A., B.G.W. and J.W.V. wrote and edited the manuscript. All authors read and approved the final manuscript.

Conflicts of Interest: The authors declare no conflict of interest. The funding agencies had no role in the design of the study, in data collection, analyses or interpretation thereof, in the writing of the manuscript or in the decision to publish the results.

\section{Abbreviations}

\begin{tabular}{|c|c|}
\hline BMI1 & B lymphoma Mo-MLV insertion region 1 \\
\hline BrdU & bromo-deoxyuridine \\
\hline ChIP & chomatin immunoprecipitation \\
\hline DDR & DNA damage response \\
\hline DPOL2 & DNA polymerase 2 \\
\hline DPOLR2 & RNA polymerase 2 \\
\hline DSB & double strand DNA breaks \\
\hline ERSS & ER-stress signaling \\
\hline GMNN & geminin \\
\hline H3K27me3 & histon H3 Lysine 27 trimethylation \\
\hline H3K9me3 & histon H3 Lysine 9 trimethylation \\
\hline $\mathrm{HZ}$ & hypertrophic zone \\
\hline IF & immunofluorescence \\
\hline KD & knockdown \\
\hline KMD & Lysine demethylase \\
\hline KMT & Lysine methyl transferase \\
\hline $\mathrm{OE}$ & overexpression \\
\hline OIS & oncogene induced senescence \\
\hline PHC2 & Polyhomeotic 2 \\
\hline pid & post-induction of differentiation \\
\hline PRC & Polycomb repressive complex \\
\hline pre-HZ & pre-hypertrophic zone \\
\hline PZ & proliferative zone \\
\hline RING1 & really interesting new gene $1 \mathrm{~A}$ \\
\hline RNF2 & ring-finger protein 2 \\
\hline SA-bGAL & senescence associated beta-galactosidase \\
\hline SASP & senescence-associated Secretory phenotype \\
\hline shcon & control shRNA \\
\hline shRNA & short hairpin RNA \\
\hline SLR & senescence like response \\
\hline SMS & senescence messaging secretome \\
\hline TA & transit amplification \\
\hline TOP2A & topoisomerase 2 \\
\hline
\end{tabular}


TrxG Trithorax group proteins

UPR unfolded protein response

yH2A.X H2A.X Serine 139 phosphorylation

\section{References}

1. Prezioso, C.; Orlando, V. Polycomb proteins in mammalian cell differentiation and plasticity. FEBS Lett. 2011, 585, 2067-2077. [CrossRef] [PubMed]

2. Müller, J.; Verrijzer, P. Biochemical mechanisms of gene regulation by polycomb group protein complexes. Curr. Opin. Genet. Dev. 2009, 19, 1-9. [CrossRef] [PubMed]

3. Simon, J.A. Chromatin compaction at Hox loci: A polycomb tale beyond histone tails. Mol. Cell 2010, 38, 321-322. [CrossRef] [PubMed]

4. Deschamps, J.; van den Akker, E.; Forlani, S.; De Graaff, W.; Oosterveen, T.; Roelen, B.; Roelfsema, J. Initiation, establishment and maintenance of Hox gene expression patterns in the mouse. Int. J. Dev. Biol. 1999, 43, 635-650. [PubMed]

5. Scelfo, A.; Piunti, A.; Pasini, D. The controversial role of the polycomb group proteins in transcription and cancer: How much do we not understand polycomb proteins? FEBS J. 2015, 282, 1703-1722. [CrossRef] [PubMed]

6. Van Lohuizen, M. Functional analysis of mouse polycomb group genes. Cell. Mol. Life Sci. 1998, 54, 71-79. [CrossRef] [PubMed]

7. O'Dor, E.; Beck, S.A.; Brock, H.W. Polycomb group mutants exhibit mitotic defects in syncytial cell cycles of drosophila embryos. Dev. Biol. 2005. [CrossRef] [PubMed]

8. Soshnikova, N.; Duboule, D. Epigenetic regulation of vertebrate Hox genes: A dynamic equilibrium. Epigenetics 2009, 4, 537-540. [CrossRef] [PubMed]

9. Martinez, A.M.; Cavalli, G. The role of polycomb group proteins in cell cycle regulation during development. Cell Cycle 2006, 5, 1189-1197. [CrossRef] [PubMed]

10. Sparmann, A.; van Lohuizen, M. Polycomb silencers control cell fate, development and cancer. Nat. Rev. Cancer 2006, 6, 846-856. [CrossRef] [PubMed]

11. Ismail, I.H.; Andrin, C.; McDonald, D.; Hendzel, M.J. BMI1-mediated histone ubiquitylation promotes DNA double-strand break repair. J. Cell Biol. 2010, 191, 45-60. [CrossRef] [PubMed]

12. Gieni, R.S.; Ismail, I.H.; Campbell, S.; Hendzel, M.J. Polycomb group proteins in the DNA damage response: A link between radiation resistance and "stemness". Cell Cycle 2011, 10, 883-894. [CrossRef] [PubMed]

13. Voncken, J.W.; Roelen, B.A.; Roefs, M.; de Vries, S.; Verhoeven, E.; Marino, S.; Deschamps, J.; van Lohuizen, M. Rnf2 (RING1b) deficiency causes gastrulation arrest and cell cycle inhibition. Proc. Natl. Acad. Sci. USA 2003, 100, 2468-2473. [CrossRef] [PubMed]

14. Lessard, J.; Sauvageau, G. BMI-1 determines the proliferative capacity of normal and leukaemic stem cells. Nature 2003, 423, 255-260. [CrossRef] [PubMed]

15. Molofsky, A.V.; He, S.; Bydon, M.; Morrison, S.J.; Pardal, R. BMI-1 promotes neural stem cell self-renewal and neural development but not mouse growth and survival by repressing the p16ink4a and p19arf senescence pathways. Genes Dev. 2005, 19, 1432-1437. [CrossRef] [PubMed]

16. Park, I.K.; Morrison, S.J.; Clarke, M.F. BMI1, stem cells and senescence regulation. J. Clin. Investig. 2004, 113, 175-179. [CrossRef] [PubMed]

17. Lapthanasupkul, P.; Feng, J.; Mantesso, A.; Takada-Horisawa, Y.; Vidal, M.; Koseki, H.; Wang, L.; An, Z.; Miletich, I.; Sharpe, P.T. RING1a/b polycomb proteins regulate the mesenchymal stem cell niche in continuously growing incisors. Dev. Biol. 2012, 367, 140-153. [CrossRef] [PubMed]

18. Itzkovitz, S.; Lyubimova, A.; Blat, I.C.; Maynard, M.; van Es, J.; Lees, J.; Jacks, T.; Clevers, H.; van Oudenaarden, A. Single-molecule transcript counting of stem-cell markers in the mouse intestine. Nat. Cell Biol. 2012, 14, 106-114. [CrossRef] [PubMed]

19. Spaapen, F.; van den Akker, G.G.; Caron, M.M.; Prickaerts, P.; Rofel, C.; Dahlmans, V.E.; Surtel, D.A.; Paulis, Y.; Schweizer, F.; Welting, T.J.; et al. The immediate early gene product EGR1 and polycomb group proteins interact in epigenetic programming during chondrogenesis. PLoS ONE 2013, 8, e58083. [CrossRef] [PubMed] 
20. Mackie, E.J.; Ahmed, Y.A.; Tatarczuch, L.; Chen, K.S.; Mirams, M. Endochondral ossification: How cartilage is converted into bone in the developing skeleton. Int. J. Biochem. Cell Biol. 2008, 40, 46-62. [CrossRef] [PubMed]

21. Atsumi, T.; Miwa, Y.; Kimata, K.; Ikawa, Y. A chondrogenic cell line derived from a differentiating culture of AT805 teratocarcinoma cells. Cell Differ. Dev. 1990, 30, 109-116. [CrossRef]

22. Suzuki, M.; Mizutani-Koseki, Y.; Fujimura, Y.; Miyagishima, H.; Kaneko, T.; Takada, Y.; Akasaka, T.; Tanzawa, H.; Takihara, Y.; Nakano, M.; et al. Involvement of the polycomb-group gene RING1b in the specification of the anterior-posterior axis in mice. Development 2002, 129, 4171-4183. [PubMed]

23. Van der Lugt, N.M.; Domen, J.; Linders, K.; van Roon, M.; Robanus-Maandag, E.; te Riele, H.; van der Valk, M.; Deschamps, J.; Sofroniew, M.; van Lohuizen, M.; et al. Posterior transformation, neurological abnormalities and severe hematopoietic defects in mice with a targeted deletion of the bmi-1 proto-oncogene. Genes Dev. 1994, 8, 757-769. [CrossRef] [PubMed]

24. Isono, K.; Fujimura, Y.; Shinga, J.; Yamaki, M.; O-Wang, J.; Takihara, Y.; Murahashi, Y.; Takada, Y.; Mizutani-Koseki, Y.; Koseki, H. Mammalian polyhomeotic homologues Phc2 and Phc1 act in synergy to mediate polycomb repression of Hox genes. Mol. Cell. Biol. 2005, 25, 6694-6706. [CrossRef] [PubMed]

25. Bel, S.; Core, N.; Djabali, M.; Kieboom, K.; Van der, L.N.; Alkema, M.J.; van Lohuizen, M. Genetic interactions and dosage effects of polycomb group genes in mice. Development 1998, 125, 3543-3551. [PubMed]

26. Del Mar, L.M.; Marcos-Gutierrez, C.; Perez, C.; Schoorlemmer, J.; Ramirez, A.; Magin, T.; Vidal, M. Lossand gain-of-function mutations show a polycomb group function for ring1a in mice. Development 2000, 127, 5093-5100.

27. Celis, J.E.; Celis, A. Cell cycle-dependent variations in the distribution of the nuclear protein cyclin proliferating cell nuclear antigen in cultured cells: Subdivision of s phase. Proc. Natl. Acad. Sci. USA 1985, 82, 3262-3266. [CrossRef] [PubMed]

28. Di Micco, R.; Fumagalli, M.; d'Adda di Fagagna, F. Breaking news: High-speed race ends in arrest-How oncogenes induce senescence. Trends Cell Biol. 2007, 17, 529-536. [CrossRef] [PubMed]

29. Rogakou, E.P.; Pilch, D.R.; Orr, A.H.; Ivanova, V.S.; Bonner, W.M. DNA double-stranded breaks induce histone H2AX phosphorylation on serine 139. J. Biol. Chem. 1998, 273, 5858-5868. [CrossRef] [PubMed]

30. Pommier, Y.; Redon, C.; Rao, V.A.; Seiler, J.A.; Sordet, O.; Takemura, H.; Antony, S.; Meng, L.; Liao, Z.; Kohlhagen, G.; et al. Repair of and checkpoint response to topoisomerase I-mediated DNA damage. Mutat. Res. Fundam. Mol. Mech. Mutagen. 2003, 532, 173-203. [CrossRef]

31. Fisher, C.L.; Fisher, A.G. Chromatin states in pluripotent, differentiated and reprogrammed cells. Curr. Opin. Genet. Dev. 2011, 21, 140-146. [CrossRef] [PubMed]

32. Surface, L.E.; Thornton, S.R.; Boyer, L.A. Polycomb group proteins set the stage for early lineage commitment. Cell Stem Cell 2010, 7, 288-298. [CrossRef] [PubMed]

33. Prickaerts, P.; Adriaens, M.E.; Beucken, T.V.D.; Koch, E.; Dubois, L.; Dahlmans, V.E.H.; Gits, C.; Evelo, C.T.A.; Chan-Seng-Yue, M.; Wouters, B.G.; et al. Hypoxia increases genome-wide bivalent epigenetic marking by specific gain of H3K27me3. Epigenetics Chromatin 2016, 9, 46. [CrossRef] [PubMed]

34. Roca, J. Topoisomerase II: A fitted mechanism for the chromatin landscape. Nucleic Acids Res. 2009, 37, 721-730. [CrossRef] [PubMed]

35. Leppard, J.B.; Champoux, J.J. Human DNA topoisomerase I: Relaxation, roles and damage control. Chromosoma 2005, 114, 75-85. [CrossRef] [PubMed]

36. Petruk, S.; Sedkov, Y.; Johnston, D.M.; Hodgson, J.W.; Black, K.L.; Kovermann, S.K.; Beck, S.; Canaani, E.; Brock, H.W.; Mazo, A. TrxG and PcG proteins but not methylated histones remain associated with DNA through replication. Cell 2012, 150, 922-933. [CrossRef] [PubMed]

37. Lupo, R.; Breiling, A.; Bianchi, M.E.; Orlando, V. Drosophila chromosome condensation proteins topoisomerase II and barren colocalize with polycomb and maintain Fab-7 PRE silencing. Mol. Cell 2001, 7, 127-136. [CrossRef]

38. Piunti, A.; Rossi, A.; Cerutti, A.; Albert, M.; Jammula, S.; Scelfo, A.; Cedrone, L.; Fragola, G.; Olsson, L.; Koseki, H.; et al. Polycomb proteins control proliferation and transformation independently of cell cycle checkpoints by regulating DNA replication. Nat. Commun. 2014, 5, 3649. [CrossRef] [PubMed] 
39. Alchanati, I.; Teicher, C.; Cohen, G.; Shemesh, V.; Barr, H.M.; Nakache, P.; Ben-Avraham, D.; Idelevich, A.; Angel, I.; Livnah, N.; et al. The E3 ubiquitin-ligase Bmi1/Ring1A controls the proteasomal degradation of top $2 \alpha$ cleavage complex-A potentially new drug target. PLoS ONE 2009, 4, e8104. [CrossRef] [PubMed]

40. Deweese, J.E.; Osheroff, N. The DNA cleavage reaction of topoisomerase II: Wolf in sheep's clothing. Nucleic Acids Res. 2009, 37, 738-748. [CrossRef] [PubMed]

41. Lehmann, L.; Ferrari, R.; Vashisht, A.A.; Wohlschlegel, J.A.; Kurdistani, S.K.; Carey, M. Polycomb repressive complex 1 (PRC1) disassembles RNA polymerase II preinitiation complexes. J. Biol. Chem. 2012, 287, 35784-35794. [CrossRef] [PubMed]

42. Hsin, J.P.; Manley, J.L. The RNA polymerase II CTD coordinates transcription and RNA processing. Genes Dev. 2012, 26, 2119-2137. [CrossRef] [PubMed]

43. Saxowsky, T.T.; Doetsch, P.W. RNA polymerase encounters with DNA damage: Transcription-coupled repair or transcriptional mutagenesis? Chem. Rev. 2006, 106, 474-488. [CrossRef] [PubMed]

44. Sordet, O.; Larochelle, S.; Nicolas, E.; Stevens, E.V.; Zhang, C.; Shokat, K.M.; Fisher, R.P.; Pommier, Y. Hyperphosphorylation of RNA polymerase II in response to topoisomerase I cleavage complexes and its association with transcription- and BRCA1-dependent degradation of topoisomerase I. J. Mol. Biol. 2008, 381, 540-549. [CrossRef] [PubMed]

45. Lim, J.W.; Hummert, P.; Mills, J.C.; Kroll, K.L. Geminin cooperates with polycomb to restrain multi-lineage commitment in the early embryo. Development 2010, 138, 33-44. [CrossRef] [PubMed]

46. Ohtsubo, M.; Yasunaga, S.; Ohno, Y.; Tsumura, M.; Okada, S.; Ishikawa, N.; Shirao, K.; Kikuchi, A.; Nishitani, H.; Kobayashi, M.; et al. Polycomb-group complex 1 acts as an E3 ubiquitin ligase for geminin to sustain hematopoietic stem cell activity. Proc. Natl. Acad. Sci. USA 2008, 105, 10396-10401. [CrossRef] [PubMed]

47. Melixetian, M.; Helin, K. Geminin: A major DNA replication safeguard in higher eukaryotes. Cell Cycle 2004, 3, 1002-1004. [CrossRef] [PubMed]

48. Luo, L.; Yang, X.; Takihara, Y.; Knoetgen, H.; Kessel, M. The cell-cycle regulator geminin inhibits Hox function through direct and polycomb-mediated interactions. Nature 2004, 427, 749-753. [CrossRef] [PubMed]

49. Narita, M. Cellular senescence and chromatin organisation. Br. J. Cancer 2007, 96, 686-691. [CrossRef] [PubMed]

50. Rodier, F.; Coppe, J.P.; Patil, C.K.; Hoeijmakers, W.A.; Munoz, D.P.; Raza, S.R.; Freund, A.; Campeau, E.; Davalos, A.R.; Campisi, J. Persistent DNA damage signalling triggers senescence-associated inflammatory cytokine secretion. Nat. Cell Biol. 2009, 11, 973-979. [CrossRef] [PubMed]

51. Kuilman, T.; Peeper, D.S. Senescence-messaging secretome: SMS-ing cellular stress. Nat. Rev. Cancer 2009, 9, 81-94. [CrossRef] [PubMed]

52. Fasano, C.A.; Dimos, J.T.; Ivanova, N.B.; Lowry, N.; Lemischka, I.R.; Temple, S. shRNA knockdown of Bmi-1 reveals a critical role for $\mathrm{p} 21-\mathrm{Rb}$ pathway in NSC self-renewal during development. Cell Stem Cell 2007, 1, 87-99. [CrossRef] [PubMed]

53. Negishi, M.; Saraya, A.; Miyagi, S.; Nagao, K.; Inagaki, Y.; Nishikawa, M.; Tajima, S.; Koseki, H.; Tsuda, H.; Takasaki, Y.; et al. BMI1 cooperates with Dnmt1-associated protein 1 in gene silencing. Biochem. Biophys. Res. Commun. 2007, 353, 992-998. [CrossRef] [PubMed]

54. Dimri, G.P.; Lee, X.; Basile, G.; Acosta, M.; Scott, G.; Roskelley, C.; Medrano, E.E.; Linskens, M.; Rubelj, I.; Pereira-Smith, O.; et al. A biomarker that identifies senescent human cells in culture and in aging skin in vivo. Proc. Natl. Acad. Sci. USA 1995, 92, 9363-9367. [CrossRef] [PubMed]

55. Prickaerts, P.; Niessen, H.E.C.; Mouchel-Vielh, E.; Dahlmans, V.E.H.; van den Akker, G.G.H.; Geijselaers, C.; Adriaens, M.E.; Spaapen, F.; Takihara, Y.; Rapp, U.R.; et al. MK3 controls polycomb target gene expression via negative feedback on ERK. Epigenetics Chromatin 2012, 5, 12. [CrossRef] [PubMed]

56. Vanhove, J.; Pistoni, M.; Welters, M.; Eggermont, K.; Vanslembrouck, V.; Helsen, N.; Boon, R.; Najimi, M.; Sokal, E.; Collas, P.; et al. H3K27me3 does not orchestrate the expression of lineage-specific markers in hesc-derived hepatocytes in vitro. Stem Cell Rep. 2016, 7, 192-206. [CrossRef] [PubMed]

57. Adriaens, M.E.; Prickaerts, P.; Chan-Seng-Yue, M.; van den Beucken, T.; Dahlmans, V.E.H.; Eijssen, L.M.; Beck, T.; Wouters, B.G.; Voncken, J.W.; Evelo, C.T.A. Quantitative analysis of ChIP-seq data uncovers dynamic and sustained H3K4me3 and H3K27me3 modulation in cancer cells under hypoxia. Epigenetics Chromatin 2016, 9, 48. [CrossRef] [PubMed] 
58. Morey, L.; Santanach, A.; Blanco, E.; Aloia, L.; Nora, E.P.; Bruneau, B.G.; Di Croce, L. Polycomb regulates mesoderm cell fate-specification in embryonic stem cells through activation and repression mechanisms. Cell Stem Cell 2015, 17, 300-315. [CrossRef] [PubMed]

59. Gao, Z.; Lee, P.; Stafford, J.M.; von Schimmelmann, M.; Schaefer, A.; Reinberg, D. An AUTS2-Polycomb complex activates gene expression in the CNS. Nature 2014, 516, 349-354. [CrossRef] [PubMed]

60. Schaaf, C.A.; Misulovin, Z.; Gause, M.; Koenig, A.; Gohara, D.W.; Watson, A.; Dorsett, D. Cohesin and polycomb proteins functionally interact to control transcription at silenced and active genes. PLoS Genet. 2013, 9, e1003560. [CrossRef] [PubMed]

61. Frangini, A.; Sjoberg, M.; Roman-Trufero, M.; Dharmalingam, G.; Haberle, V.; Bartke, T.; Lenhard, B.; Malumbres, M.; Vidal, M.; Dillon, N. The aurora B kinase and the polycomb protein RING1B combine to regulate active promoters in quiescent lymphocytes. Mol. Cell 2013, 51, 647-661. [CrossRef] [PubMed]

62. Creppe, C.; Palau, A.; Malinverni, R.; Valero, V.; Buschbeck, M. A cbx8-containing polycomb complex facilitates the transition to gene activation during ES cell differentiation. PLoS Genet. 2014, 10, e1004851. [CrossRef] [PubMed]

63. Fragola, G.; Germain, P.L.; Laise, P.; Cuomo, A.; Blasimme, A.; Gross, F.; Signaroldi, E.; Bucci, G.; Sommer, C.; Pruneri, G.; et al. Cell reprogramming requires silencing of a core subset of polycomb targets. PLoS Genet. 2013, 9, e1003292. [CrossRef] [PubMed]

64. Patel, T.; Tursun, B.; Rahe, D.P.; Hobert, O. Removal of polycomb repressive complex 2 makes C. Elegans germ cells susceptible to direct conversion into specific somatic cell types. Cell Rep. 2012, 2, 1178-1186. [CrossRef] [PubMed]

65. Hemberger, M.; Dean, W.; Reik, W. Epigenetic dynamics of stem cells and cell lineage commitment: Digging waddington's canal. Nat. Rev. Mol. Cell Biol. 2009, 10, 526-537. [CrossRef] [PubMed]

66. Zhang, F.; Xu, L.; Xu, Q.; Li, D.; Yang, Y.; Karsenty, G.; Chen, C.D. JMJD3 promotes chondrocyte proliferation and hypertrophy during endochondral bone formation in mice. J. Mol. Cell Biol. 2015, 7, 23-34. [CrossRef] [PubMed]

67. Fullgrabe, J.; Hajji, N.; Joseph, B. Cracking the death code: Apoptosis-related histone modifications. Cell Death Differ. 2010, 17, 1238-1243. [CrossRef] [PubMed]

68. Basenko, E.Y.; Sasaki, T.; Ji, L.; Prybol, C.J.; Burckhardt, R.M.; Schmitz, R.J.; Lewis, Z.A. Genome-wide redistribution of H3K27me3 is linked to genotoxic stress and defective growth. Proc. Natl. Acad. Sci. USA 2015, 112, E6339-E6348. [CrossRef] [PubMed]

69. Hansen, K.H.; Bracken, A.P.; Pasini, D.; Dietrich, N.; Gehani, S.S.; Monrad, A.; Rappsilber, J.; Lerdrup, M.; Helin, K. A model for transmission of the H3K27me3 epigenetic mark. Nat. Cell Biol. 2008, 10, 1291-1300. [CrossRef] [PubMed]

70. Wei, X.; Samarabandu, J.; Devdhar, R.S.; Siegel, A.J.; Acharya, R.; Berezney, R. Segregation of transcription and replication sites into higher order domains. Science 1998, 281, 1502-1506. [CrossRef] [PubMed]

71. Branzei, D.; Foiani, M. The checkpoint response to replication stress. DNA Repair (Amst.) 2009, 8, 1038-1046. [CrossRef] [PubMed]

72. Rudolph, C.J.; Dhillon, P.; Moore, T.; Lloyd, R.G. Avoiding and resolving conflicts between DNA replication and transcription. DNA Repair (Amst.) 2007, 6, 981-993. [CrossRef] [PubMed]

73. Voncken, J.W.; Schweizer, D.; Aagaard, L.; Sattler, L.; Jantsch, M.F.; van Lohuizen, M. Chromatin-association of the polycomb group protein BMI1 is cell cycle-regulated and correlates with its phosphorylation status. J. Cell Sci. 1999, 112 (Pt 24), 4627-4639. [PubMed]

74. Francis, N.J.; Follmer, N.E.; Simon, M.D.; Aghia, G.; Butler, J.D. Polycomb proteins remain bound to chromatin and DNA during DNA replication in vitro. Cell 2009, 137, 110-122. [CrossRef] [PubMed]

75. Breiling, A.; O'Neill, L.P.; D'Eliseo, D.; Turner, B.M.; Orlando, V. Epigenome changes in active and inactive polycomb-group-controlled regions. EMBO Rep. 2004, 5, 976-982. [CrossRef] [PubMed]

76. Wang, H.; Wang, L.; Erdjument-Bromage, H.; Vidal, M.; Tempst, P.; Jones, R.S.; Zhang, Y. Role of histone H2A ubiquitination in polycomb silencing. Nature 2004, 431, 873-878. [CrossRef] [PubMed]

77. Tavares, L.; Dimitrova, E.; Oxley, D.; Webster, J.; Poot, R.; Demmers, J.; Bezstarosti, K.; Taylor, S.; Ura, H.; Koide, H.; et al. RYBP-PRC1 complexes mediate H2A ubiquitylation at polycomb target sites independently of PRC2 and H3K27me3. Cell 2012, 148, 664-678. [CrossRef] [PubMed] 
78. Vissers, J.H.; Nicassio, F.; van Lohuizen, M.; Di Fiore, P.P.; Citterio, E. The many faces of ubiquitinated histone H2A: Insights from the dubs. Cell Div. 2008, 3, 8. [CrossRef] [PubMed]

79. Niessen, H.E.; Demmers, J.A.; Voncken, J.W. Talking to chromatin: Post-translational modulation of polycomb group function. Epigenetics Chromatin 2009, 2, 10. [CrossRef] [PubMed]

80. Gil, J.; O'Loghlen, A. PRC1 complex diversity: Where is it taking us? Trends Cell Biol. 2014, 24, 632-641. [CrossRef] [PubMed]

81. Schuettengruber, B.; Cavalli, G. Recruitment of polycomb group complexes and their role in the dynamic regulation of cell fate choice. Development 2009, 136, 3531-3542. [CrossRef] [PubMed]

82. Azuara, V.; Perry, P.; Sauer, S.; Spivakov, M.; Jorgensen, H.F.; John, R.M.; Gouti, M.; Casanova, M.; Warnes, G.; Merkenschlager, M.; et al. Chromatin signatures of pluripotent cell lines. Nat. Cell Biol. 2006, 8, 532-538. [CrossRef] [PubMed]

83. Zuscik, M.J. Regulation of chondrogenesis and chondrocyte differentiation by stress. J. Clin. Investig. 2008, 118, 429-438. [CrossRef] [PubMed]

84. Saito, A.; Hino, S.; Murakami, T.; Kanemoto, S.; Kondo, S.; Saitoh, M.; Nishimura, R.; Yoneda, T.; Furuichi, T.; Ikegawa, S.; et al. Regulation of endoplasmic reticulum stress response by a BBF2H7-mediated Sec23a pathway is essential for chondrogenesis. Nat. Cell Biol. 2009, 11, 1197-1204. [CrossRef] [PubMed]

85. Settembre, C.; Arteaga-Solis, E.; McKee, M.D.; de Pablo, R.; Al Awqati, Q.; Ballabio, A.; Karsenty, G. Proteoglycan desulfation determines the efficiency of chondrocyte autophagy and the extent of FGF signaling during endochondral ossification. Genes Dev. 2008, 22, 2645-2650. [CrossRef] [PubMed]

86. Denoyelle, C.; Abou-Rjaily, G.; Bezrookove, V.; Verhaegen, M.; Johnson, T.M.; Fullen, D.R.; Pointer, J.N.; Gruber, S.B.; Su, L.D.; Nikiforov, M.A.; et al. Anti-oncogenic role of the endoplasmic reticulum differentially activated by mutations in the MAPK pathway. Nat. Cell Biol. 2006, 8, 1053-1063. [CrossRef] [PubMed]

87. Kilbey, A.; Terry, A.; Cameron, E.R.; Neil, J.C. Oncogene-induced senescence: An essential role for Runx. Cell Cycle 2008, 7, 2333-2340. [PubMed]

88. Yoshida, C.A.; Komori, T. Role of Runx proteins in chondrogenesis. Crit. Rev. Eukaryot. Gene Expr. 2005, 15, 243-254. [CrossRef] [PubMed]

89. Datta, S.; Hoenerhoff, M.J.; Bommi, P.; Sainger, R.; Guo, W.-J.; Dimri, M.; Band, H.; Band, V.; Green, J.E.; Dimri, G.P. Bmi-1 cooperates with H-Ras to transform human mammary epithelial cells via dysregulation of multiple growth-regulatory pathways. Cancer Res. 2007, 67, 10286-10295. [CrossRef] [PubMed]

90. Lee, T.I.; Jenner, R.G.; Boyer, L.A.; Guenther, M.G.; Levine, S.S.; Kumar, R.M.; Chevalier, B.; Johnstone, S.E.; Cole, M.F.; Isono, K.; et al. Control of developmental regulators by polycomb in human embryonic stem cells. Cell 2006, 125, 301-313. [CrossRef] [PubMed]

91. Boyer, L.A.; Plath, K.; Zeitlinger, J.; Brambrink, T.; Medeiros, L.A.; Lee, T.I.; Levine, S.S.; Wernig, M.; Tajonar, A.; Ray, M.K.; et al. Polycomb complexes repress developmental regulators in murine embryonic stem cells. Nature 2006, 441, 349-353. [CrossRef] [PubMed]

92. Bernstein, B.E.; Mikkelsen, T.S.; Xie, X.; Kamal, M.; Huebert, D.J.; Cuff, J.; Fry, B.; Meissner, A.; Wernig, M.; Plath, K.; et al. A bivalent chromatin structure marks key developmental genes in embryonic stem cells. Cell 2006, 125, 315-326. [CrossRef] [PubMed]

93. Bracken, A.P.; Dietrich, N.; Pasini, D.; Hansen, K.H.; Helin, K. Genome-wide mapping of polycomb target genes unravels their roles in cell fate transitions. Genes Dev. 2006, 20, 1123-1136. [CrossRef] [PubMed]

94. Lin, T.; Chao, C.; Saito, S.; Mazur, S.J.; Murphy, M.E.; Appella, E.; Xu, Y. p53 induces differentiation of mouse embryonic stem cells by suppressing Nanog expression. Nat. Cell Biol. 2005, 7, 165-171. [CrossRef] [PubMed]

95. Morgenstern, J.P.; Land, H. Advanced mammalian gene transfer: High titre retroviral vectors with multiple drug selection markers and a complementary helper-free packaging cell line. Nucleic Acids Res. 1990, 18, 3587-3596. [CrossRef] [PubMed]

96. Kinsella, T.M.; Nolan, G.P. Episomal vectors rapidly and stably produce high-titer recombinant retrovirus. Hum.Gene Ther. 1996, 7, 1405-1413. [CrossRef] [PubMed]

97. Brummelkamp, T.R.; Bernards, R.; Agami, R. A system for stable expression of short interferingRNAs in mammalian cells. Science 2002, 296, 550-553. [CrossRef] [PubMed]

98. Goodarzi, A.A.; Noon, A.T.; Deckbar, D.; Ziv, Y.; Shiloh, Y.; Löbrich, M.; Jeggo, P.A. ATM signaling facilitates repair of DNA double-strand breaks associated with heterochromatin. Mol. Cell 2008, 31, 167-177. [CrossRef] [PubMed] 
99. Yamaki, M.; Isono, K.; Takada, Y.; Abe, K.; Akasaka, T.; Tanzawa, H.; Koseki, H. The mouse Edr2 (Mph2) gene has two forms of mRNA encoding 90- and 36-kDa polypeptides. Gene 2002, 288, 103-110. [CrossRef]

100. Hamer, K.M.; Sewalt, R.G.; den Blaauwen, J.L.; Hendrix, T.; Satijn, D.P.; Otte, A.P. A panel of monoclonal antibodies against human polycomb group proteins. Hybrid. Hybridomics 2002, 21, 245-252. [CrossRef] [PubMed]

101. Eijssen, L.M.; Jaillard, M.; Adriaens, M.E.; Gaj, S.; de Groot, P.J.; Muller, M.; Evelo, C.T. User-friendly solutions for microarray quality control and pre-processing on arrayanalysis.Org. Nucleic Acids Res. 2013, 41, W71-W76. [CrossRef] [PubMed]

102. Gentleman, R.C.; Carey, V.J.; Bates, D.M.; Bolstad, B.; Dettling, M.; Dudoit, S.; Ellis, B.; Gautier, L.; Ge, Y.; Gentry, J.; et al. Bioconductor: Open software development for computational biology and bioinformatics. Genome Biol. 2004, 5, R80. [CrossRef] [PubMed]

103. Wu, Z.J.; Irizarry, R.A.; Gentleman, R.; Martinez-Murillo, F.; Spencer, F. A model-based background adjustment for oligonucleotide expression arrays. J. Am. Stat. Assoc. 2004, 99, 909-917. [CrossRef]

104. Dai, M.; Wang, P.; Boyd, A.D.; Kostov, G.; Athey, B.; Jones, E.G.; Bunney, W.E.; Myers, R.M.; Speed, T.P.; Akil, H.; et al. Evolving gene/transcript definitions significantly alter the interpretation of GeneChip data. Nucleic Acids Res. 2005, 33, e175. [CrossRef] [PubMed]

105. Salomonis, N.; Hanspers, K.; Zambon, A.C.; Vranizan, K.; Lawlor, S.C.; Dahlquist, K.D.; Doniger, S.W.; Stuart, J.; Conklin, B.R.; Pico, A.R. Genmapp 2: New features and resources for pathway analysis. BMC Bioinform. 2007, 8, 217. [CrossRef] [PubMed]

106. Kelder, T.; van Iersel, M.P.; Hanspers, K.; Kutmon, M.; Conklin, B.R.; Evelo, C.T.; Pico, A.R. Wikipathways: Building research communities on biological pathways. Nucleic Acids Res. 2012, 40, D1301-D1307. [CrossRef] [PubMed]

107. Marks, H.; Kalkan, T.; Menafra, R.; Denissov, S.; Jones, K.; Hofemeister, H.; Nichols, J.; Kranz, A.; Stewart, A.F.; Smith, A.; et al. The transcriptional and epigenomic foundations of ground state pluripotency. Cell 2012, 149, 590-604. [CrossRef] [PubMed] 